\title{
Evaluation of Tourism-Climate Conditions in the Region of Kłodzko Land (Poland)
}

\author{
Bartłomiej Miszuk (D)
}

Citation: Miszuk, B. Evaluation of Tourism-Climate Conditions in the Region of Kłodzko Land (Poland). Atmosphere 2021, 12, 907. https:// doi.org/10.3390/atmos12070907

Academic Editor: M. Belén Gómez Martín

Received: 23 May 2021

Accepted: 10 July 2021

Published: 14 July 2021

Publisher's Note: MDPI stays neutral with regard to jurisdictional claims in published maps and institutional affiliations.

Copyright: (C) 2021 by the author. Licensee MDPI, Basel, Switzerland. This article is an open access article distributed under the terms and conditions of the Creative Commons Attribution (CC BY) license (https:// creativecommons.org/licenses/by/ $4.0 /)$.
Institute of Meteorology and Water Management-National Research Institute, Parkowa 30, 51-616 Wrocław, Poland; Bartlomiej.Miszuk@imgw.pl

\begin{abstract}
Kłodzko Land is one of the most important regions of Poland in terms of tourism and health issues. Numerous tourism attractions and health resorts make the region attractive for both tourist and bathers. The goal of this paper was to evaluate the impact of weather conditions on tourism-related conditions and their changes in the multiannual period. In the analysis, the indices of heat days, the UTCI (Universal Thermal Climate Index) and CTIS (Climate Tourism Information Scheme) tools were used. The research on heat days and the UTCI indicated a significant increase in the heat-stress frequency over the last decades. Simultaneously, the number of weather types related to cold stress has considerably decreased. Such trends were noticed in the entire region, in all the considered hypsometric zones. The rising tendency was also observed for strong and very strong heat stress (UTCI $>32{ }^{\circ} \mathrm{C}$ ), which negatively affects health problems. The analysis showed that the most extreme thermal and biothermal conditions, in terms of heat stress, occur under southern and eastern anticyclonic circulation. The CTIS analysis showed that favorable weather conditions for most of tourism activities are noticed in the warm half-year. The usefulness of weather conditions for tourism can vary depending on atmospheric circulation.
\end{abstract}

Keywords: bioclimate; tourism; heat days; UTCI; CTIS

\section{Introduction}

Tourism is one of the most important sectors affected by climate. Air temperature, humidity, wind speed, and solar conditions have influences on the human organism, while precipitation and snow cover are significant factors for tourists. Climate conditions and their impact on the humans is noticeable, especially in the mountain regions, which are usually characterized by a high severity of climate compared to the lowlands. This concerns lower values of air temperature, higher wind speed, different humidity and solar conditions and long-lasting and thicker snow cover. Simultaneously, mountain regions are usually popular in terms of tourism. Furthermore, there are often health resorts located in these regions that make them attractive for bathers. As a result, a high number of persons, including those with health problems, are vulnerable to the influence of weather conditions in the mountains.

Tourism-climate conditions were the subject of numerous analyses concerning the indices presenting the impact of weather on humans. One of the earliest indices was the Tourism Climate Index (TCI) developed by Z. Mieczkowski [1], which considered thermal, humidity, wind, solar, and precipitation conditions, The new-generation indices include the aspect of the human heat balance and the impact of meteorological variables on tourism, including snow cover. Examples of such indices are the Weather Suitability Index (WSI) developed by K. Błażejczyk [2] and Climate Tourism Information Scheme carried out by A. Matzarakis [3-5]. Some other indices, like the Climate Index for Tourism (CTI), indicate the significance of physical and aesthetic facets of weather, considering the personal satisfaction of the tourists [6]. For the purposes of tourism-climate analysis, biothermal indices such as the Universal Thermal Climate Index (UTCI) and physiological equivalent temperature (PET) can be also used [7-10]. 
The region of Kłodzko Land, representing the Sudetes Mountains (southwest Poland), is a good example of the areas characterized by the presence of both tourism attractions and health resorts. This is one of the most important tourism regions of Poland, while numerous health resorts encourage bathers. The attractiveness of this area from the tourism perspective results from geographical variability, which makes this region favourable for trekking, rafting, skiing, and other types of tourism activities. Furthermore, the tourism value is also increased because of numerous historical objects, the Stołowe Mountains National Park, and vast natural environment areas. A very important role is played by health resorts. There are five such places located in Kłodzko Land: Duszniki-Zdrój, Kudowa-Zdrój, and Polanica-Zdrój in the western part of the region; Lądek-Zdrój, located in the west; and Długopole-Zdrój, representing the southern area. These health resorts are related to sources of valuable mineral waters and are focused on treating various illnesses, including respiratory and cardiovascular diseases. Thus, the area is often visited by persons who are extremely vulnerable to the weather factor, especially heat stress. High importance of the health resorts in the region was emphasized in the publications devoted to their problems and the relation to climate and bioclimate conditions [11-14].

One of the most noticeable factors affecting both tourists and bathers is heat stress. Research concerning the impact of this phenomenon on humans showed that in the last decades of the 20th century and in the beginning of the current millennium, heat stress was responsible for about $25 \%$ of the most significant disasters in the world [15]. Simultaneously, rising air temperature caused a high increase in heat-stress frequency over the last decades [16-28]. This resulted in extreme intensity of heat stress during the summer seasons of 2003, 2006, 2015, 2018, and 2019 [29-37], and consequently contributed to mortality growth in these seasons in Europe [33,38-43]. The mortality rate in Western Europe during the 2003 heat wave exceeded the mean value by 70,000 cases [40]. During the 2006 heat wave in Poland, the rate increased by about $25-115 \%$ in various regions [43]. It should be emphasized that the mortality growth for persons with cardiovascular diseases was even higher, and amounted to $55-220 \%$ [43]. The increase in mortality during heat waves was also noticed in the other states of Central Europe, such as Slovakia, Austria, and Hungary $[42,44,45]$. This shows that the problem of the impact of heat stress on people with such illnesses is serious, especially in the regions where numerous health resorts are located.

The influence of weather conditions on both tourism and health issues can be assessed using the Universal Thermal Climate Index (UTCI). Currently, this is the most popular and useful tool in biometeorology, and was used for evaluation of biometeorological conditions in Poland [46-54] and other European states [55-64]. The UTCI enables the assessment of biothermal conditions in terms of both cold and heat stress, as well as thermoneutral conditions. In the case of heat stress, the research showed that weather types with a UTCI exceeding $32{ }^{\circ} \mathrm{C}$ are a serious risk for persons with cardiovascular diseases $[23,47,65]$. Simultaneously, the studies also indicated that the UTCI can be higher than $40^{\circ} \mathrm{C}$ during the most intensive heat wave periods. Such conditions are also observed in the region of southwest Poland, including the lowlands [66] and the lower mountain zones of the Sudetes Mountains [48,66-68]. The entire Sudetes region in the warm half-year is characterized by a relatively low number of days with thermoneutral conditions which are the most favourable for tourists and bathers [48]. On the other hand, in the higher parts of the Sudetes Mountains, the UTCI is more often related to cold stress, while heat stress is rarely observed, or does not occur at all [48,67-69]. On the summits, cold stress prevails throughout the year, and the weather related to the most intensive cold stress can occur on more than $50 \%$ of winter days [69]. The research carried out for Kłodzko Land showed that due to significant variability in altitude, morphology, and land use, the region is characterized by a different distribution of UTCI values [70]. During solar days with a very high air temperature and low wind speed, thermal-stress categories can locally vary, from thermoneutral conditions in the highest forested mountain zones to extreme heat stress in the urban areas where the percentage of artificial surface is very high [70]. 
The aspect of thermal stress is included in the Climate Tourism Information Scheme (CTIS), which is a complex tool for the assessment of weather conditions for tourism purposes [3-5]. This evaluates climate conditions for tourism, considering both thermal stress and the vast range of meteorological variables. The CTIS was used for the assessment of climate-tourism conditions of various European areas, including the Alpine regions [4,5,71,72], the Black Forest [73,74], and southern Europe [3,75-79]. In Poland, this tool was considered in the research on the tourism potentials of the coastal region [80] and the Sudetes Mountains $[69,81,82]$. The studies on the Sudetes Mountains, which also considered other tourism-climate indices, indicated that the region is characterized by a significant spatial and temporal variability in terms of the favourability of weather for both tourism and climatotherapy $[69,81,82]$.

The impact of the weather factor on tourism was often considered in the studies concerning bioclimate conditions in this part of Europe. However, the analysis usually was based on large-scale atmospheric circulation, without consideration of the local factors. Furthermore, the papers were mainly related to some selected bioclimate aspects, but rarely concerned the entire spectrum of bioclimate conditions. In the case of the mountainous region of Kłodzko Land, the evaluation of the local atmospheric circulation is very important. In addition, the assessment of the impact of particular meteorological variables, including snow cover, is also significant because of the touristic character of the region.

The goal of this paper was to assess the main features of tourism-climate conditions in the tourism region of Kłodzko Land with a special consideration of heat stress and tourism indices. In order to examine the potential changes in the multiannual period, trends of the annual number of heat days and the categories of heat stress according to the UTCI were calculated. The high importance of tourism and health resorts in the considered region makes the result of the paper useful in terms of the improvement in knowledge on the impact of the weather factor on the sectors of tourism and public health. Furthermore, they can also be used in local guidebooks and information offices as supplementary information regarding tourism and health issues.

\section{Materials and Methods}

The analysis concerned the region of Kłodzko Land that is located in the eastern part of the Sudetes Mountains, in the Lower Silesia (southwest Poland). Geographical variability characterizes the region. The middle part is formed by the Kłodzko Valley that is stretched north to south and which is characterized by the largest area in the northern part of the region (Figure 1). The valley is surrounded by numerous mountain ridges, including: Bardzkie Mountains in the north, Bystrzyckie, Orlickie and Stołowe Mountains in the west as well as Złote Mountains and Śnieżnik Massif in the east. These ridges, along with the Międzylesie Pass in the south, form a natural border with Czechia. In the case of the Polish part of the region, the highest altitude of the mountains reaches up to $1000 \mathrm{~m}$ a.s.l. in the west (Bystrzyckie Mountains) and $1423 \mathrm{~m}$ a.s.l. in the east (Śnieżnik Mountain). Most of the Kłodzko Valley is used as agriculture area, while forests dominate in the mountains.

Meteorological data from meteorological stations of IMGW-PIB (Institute of Meteorology and Water Management-National Research Institute) in the region were used in the analysis. The records were derived from the internal database of the Institute. In this case, four stations were taken into account: Kłodzko, Długopole-Zdrój, Lądek-Zdrój and Słoszów. They represented various locations, altitudes and geographical regions (Table 1). The database concerned daily values of maximum air temperature, precipitation totals and snow cover depth. Furthermore, the meteorological data for 12:00 UTC was also used to assess biothermal conditions and climate-tourism potential in terms of CTIS. This included the values of: air temperature, relative humidity, vapour pressure, wind speed, and cloudiness. In addition, information on sun angle on particular days of the year was also considered for the purposes of the evaluation of the radiation factor. The daily data on maximum air temperature considered the 50-year period of 1971-2020. In the case of 12:00 UTC, due to data limitations for Długopole-Zdrój, Lądek Zdrój, and Słoszów, records 
for 1971-2010 were used. Therefore, the calculations of heat-day frequency were carried out for 1971-2020, while the analysis of the UTCI and CTIS were based on 1971-2010 data series. The measurement data were verified in the process of examining meteorological records, which was carried out by the meteorological service of the Institute. The data used in the paper mainly concerned maximum air temperature (for the purposes of heat-day calculations) and UTCI values for the summer seasons (June-August) of the considered periods. In order to examine the data series, the coefficient of variation was calculated for these two variables. The values of the coefficient for maximum air temperature were characterized by a relatively low variety, reaching $20-22 \%$. In the case of the UTCI, the rate was moderate and amounted to 33-38\%. In both cases, the highest variety was noticed for the areas located at the highest altitude (Słoszów).

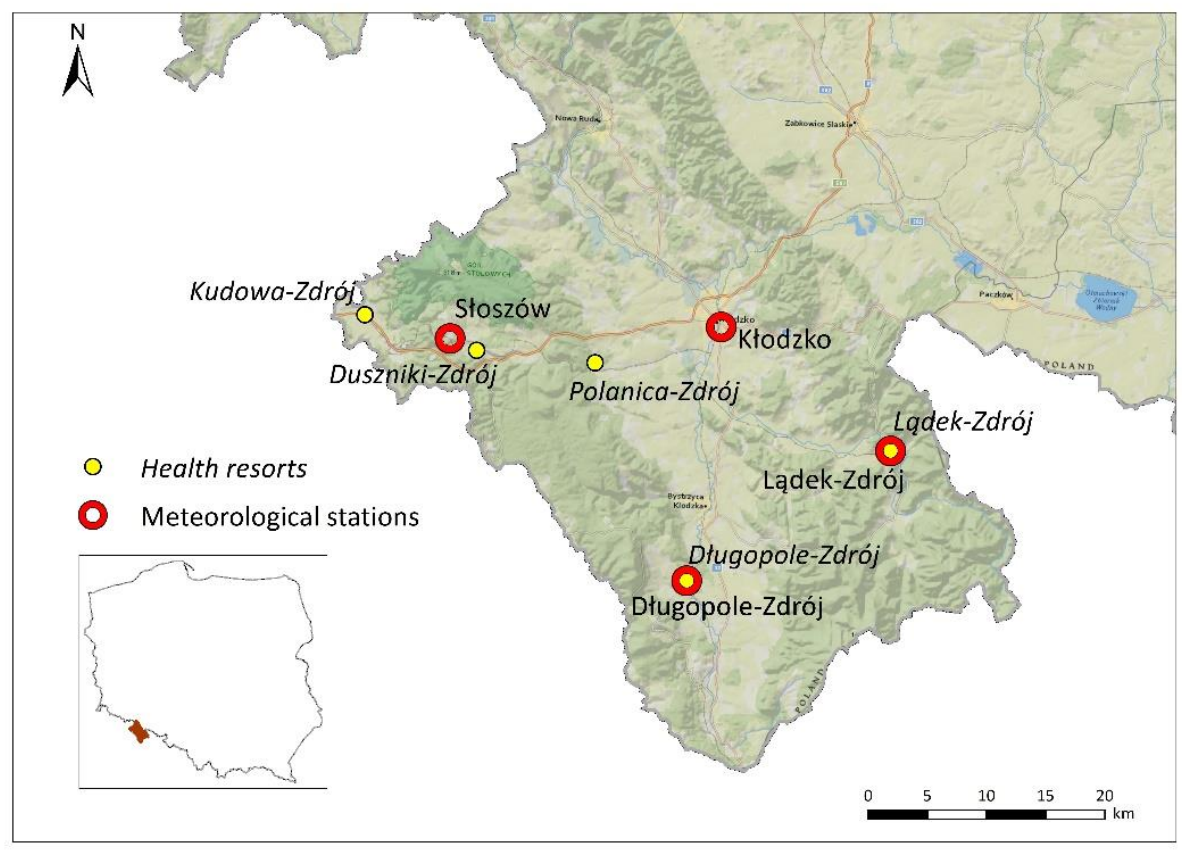

Figure 1. Location of meteorological stations and health resorts in Kłodzko Land.

Table 1. Meteorological stations in the region of Kłodzko Land (with increasing altitude).

\begin{tabular}{ccccc}
\hline Station & Region & Latitude & Longitude & Altitude (m) \\
\hline Kłodzko & Kłodzko Valley & $50^{\circ} 26^{\prime}$ & $16^{\circ} 37^{\prime}$ & 356 \\
Długople-Zdrój & Upper Nysa Kł. Graben & $50^{\circ} 15^{\prime}$ & $16^{\circ} 38^{\prime}$ & 393 \\
Ladek-Zdrój & Złote Mountains & $50^{\circ} 21^{\prime}$ & $16^{\circ} 53^{\prime}$ & 461 \\
Słoszów & Lewińskie Hills & $50^{\circ} 24^{\prime}$ & $16^{\circ} 22^{\prime}$ & 556 \\
\hline
\end{tabular}

The index of heat days, defined as weather conditions with $\mathrm{T}_{\max }>30^{\circ} \mathrm{C}$, was used to evaluate the intensity of heat stress in Kłodzko Land. The calculations were carried out for each year of the considered period, and included annual and monthly frequency. The entire spectrum of thermal stress was examined using the UTCI (Universal Thermal Climate Index). This index focuses on evaluation of biothermal conditions with a special consideration of detailed physiological aspects. The index is based on multinode models, mainly Fiala's model [83], and was comprehensively described in the papers concerning its methodology [8-10]. Depending on thermal stress, UTCI values classify biothermal conditions into 10 categories that vary from extreme cold stress to extreme heat stress (Table 2). The calculations of UTCI values were carried out for 12:00 UTC using BioKlima2.6 software [84]. Based on the values, the frequency of UTCI categories for particular years and months was assessed for each of the considered stations. 
Table 2. Stress category according to UTCI [10].

\begin{tabular}{cc}
\hline Stress Category & UTCI $\left({ }^{\circ} \mathbf{C}\right)$ \\
\hline Extreme heat & above 46 \\
Very strong heat & 38 to 46 \\
Strong heat & 32 to 38 \\
Moderate heat & 26 to 32 \\
No thermal & 9 to 26 \\
Slight cold & 0 to 9 \\
Moderate cold & -13 to 0 \\
Strong cold & -27 to -13 \\
Very strong cold & -40 to -27 \\
Extreme cold & below -40 \\
\hline
\end{tabular}

Weather potential for tourism was assessed using the Climate Tourism Information Scheme (CTIS), developed by A. Matzarakis [3-5]. This tool considers the impact of thermal stress (calculated using a biothermal index) and various meteorological variables. For the purposes of this paper, the thermal stress factor was evaluated based on UTCI categories. In this case, thermal-stress classes were divided into three groups: thermal comfort (when UTCI values were equivalent to thermoneutral conditions or slight cold stress), heat stress (concerning the UTCI categories of moderate, strong, very strong, and extreme heat stress), and cold stress (moderate, strong, very strong, and extreme cold stress). Regarding the meteorological variables affecting tourism, the factors of cloudiness $(\mathrm{N})$, relative humidity $(\mathrm{U})$, vapour pressure (e), precipitation $(\mathrm{R})$, wind speed $(\mathrm{v})$, and snow cover (HS) were taken into consideration and calculated according to the CTIS criteria (Table 3). Therefore, the region was evaluated from the perspective of solar conditions, fog-related conditions, sultriness, dry/wet conditions, the frequency of windy days, and snow potential for skiing. The aspect of snow cover was modified if compared to the original CTIS. Because of a relatively low frequency of snow cover exceeding $30 \mathrm{~cm}$ at the considered stations, the criterion was changed to $10 \mathrm{~cm}$, which is a suitable value for cross-country skiing. The calculations of the meteorological variables were carried out based on daily data (precipitations, snow cover) and for 12:00 UTC (cloudiness, relative humidity, vapour pressure, wind speed). The results of the analysis on CTIS were presented as a calendar of weather conditions for particular 10-day periods.

Table 3. Climate Tourism Information Scheme (CTIS) [3; modified].

\begin{tabular}{ccc}
\hline Factor & Criterion & Range \\
\hline & Thermal comfort & $0{ }^{\circ} \mathrm{C}<\mathrm{UTCI}<26{ }^{\circ} \mathrm{C}$ \\
Biothermal conditions & Heat stress & $\mathrm{UTCI}>26^{\circ} \mathrm{C}$ \\
& Cold stress & $\mathrm{UTCI}<0{ }^{\circ} \mathrm{C}$ \\
Sunny days & Cloudiness & $\mathrm{N}<5 / 8$ \\
Days with fog features & Relative humidity & $\mathrm{U}>93 \%$ \\
Sultry days & Vapour pressure & $\mathrm{e}>18 \mathrm{hPa}$ \\
Dry days & Precipitations & $\mathrm{R} \leq 1 \mathrm{~mm}$ \\
Wet days & Precipitations & $\mathrm{R}>5 \mathrm{~mm}$ \\
Windy days & Wind speed & $\mathrm{v}>8 \mathrm{~m} / \mathrm{s}$ \\
Snow potential & Snow cover & $\mathrm{HS}>10 \mathrm{~cm}$ \\
\hline
\end{tabular}

In order to present the most intensive heat-stress conditions and their relation to the atmospheric circulation, a calendar of circulation types developed by H. Ojrzyńska was used [85-87]. This classification concerns the Sudetes Mountains and the surrounding regions, and is based on the data related to vorticity ( $\mathrm{C}$, cyclonic; $\mathrm{A}$, anticyclonic) and the direction of advection: $\mathrm{NE}$, northeast $\left(1-90^{\circ}\right)$; SE, southeast $\left(91-180^{\circ}\right)$; SW, southwest $\left(181-270^{\circ}\right)$; NW, northwest $\left(271-360^{\circ}\right)$; and XX, indeterminate direction. The principles of the classification are gridded meteorological data $\left(2.5^{\circ} \times 2.5^{\circ}\right.$ spatial resolution, $24 \mathrm{~h}$ 
temporal resolution) from NCEP/NCAR (National Centers for Environmental Prediction/National Center for Atmospheric Research) reanalysis. These data were interpolated to a spatial resolution of $5 \mathrm{~km} \times 5 \mathrm{~km}$ using the spline function. Circulation types for particular days were assessed based on the prevailing type, which was calculated by applying the mode function for all the $5 \mathrm{~km} \times 5 \mathrm{~km}$ grid cells [86]. The types of vorticity were evaluated using geopotential values from the $850 \mathrm{hPa}$ isobaric level. In the case of the direction of advection, the wind direction from the $700 \mathrm{hPa}$ isobaric level was used. This was determined when a wind speed exceeded $2 \mathrm{~m} / \mathrm{s}$. If it was lower or when no prevailing wind direction was noticed, the XX circulation type was determined. The calendar of the circulation types was obtained directly from the author of the classification.

Based on the results, changes in some of the considered indices (heat days, UTCI) in the multiannual period were evaluated. The trends and intensity of these changes were assessed using linear regression analysis. The statistical significance was examined at a level of 0.05. In addition, the results of the calculations were verified using the MannKendall test and Sen's method. The evaluation of the changes in heat-day frequency was carried out for 1971-2020, while the data of 1971-2010 were used for the examination of UTCI trends.

\section{Results}

\subsection{Heat Days}

The impact of heat stress on humans can be assessed using the index of heat days $\left(\mathrm{T}_{\max }>30^{\circ} \mathrm{C}\right)$, including the evaluation of their frequency and changes in the multiannual period. In the region of Kłodzko Land, heat days occurred during more than 3 days a year in the lower located zones, represented by Kłodzko, Długopole-Zdrój, and Ladek-Zdrój. In Słoszów, which is located at the highest altitude, the frequency of such weather conditions in 1971-2010 was equal to less than 2 days a year (Table 4). Air temperature exceeding $30^{\circ} \mathrm{C}$ in the discussed region was observed in the warm half-year only. July and August were the months with the highest number of heat days. In the case of the three stations located lower down, weather conditions with $\mathrm{T}_{\max }>30^{\circ} \mathrm{C}$ in these months occurred on about 3 days every 2 years. In June, the frequency was lower and amounted to 1 day every 2 or 3 years in Kłodzko, Długopole-Zdrój, and Lądek-Zdrój; whereas in Słoszów, the mean frequency reached 1 day every 5 years. Besides the summer season, heat days were also sporadically observed in May and September. In May, 2-3 cases of heat days in 1971-2020 were noticed at the stations representing the lower hypsometric zones. In September, the total number of such days in the entire multiannual period varied from 2 days in Długopole-Zdrój, Lądek-Zdrój, and Słoszów to 4 days in Kłodzko.

Table 4. Mean frequency of heat days $\left(\mathrm{T}_{\max }>30^{\circ} \mathrm{C}\right)$ in the warm half-year in Kłodzko Land in 1971-2020.

\begin{tabular}{cccccccc}
\hline Station & IV & V & VI & VII & VIII & IX & Total \\
\hline Kłodzko &. & 0.0 & 0.3 & 1.4 & 1.6 & 0.1 & 3.4 \\
Długople-Zdrój &. & 0.1 & 0.4 & 1.4 & 1.4 & 0.0 & 3.3 \\
Ladek-Zdrój &. & 0.0 & 0.5 & 1.4 & 1.3 & 0.0 & 3.2 \\
Słoszów &. &. & 0.2 & 0.9 & 0.7 & 0.0 & 1.8 \\
\hline
\end{tabular}

Regarding the highest frequency of heat days in the studied period, the summer seasons of 1992, 1994, 2013, 2015, and 2018 were considered as the most extreme. During these periods, the annual number of heat days at the stations located lower down was equal to at least 10 days, while in Słoszów the frequency exceeded 5 days. The most heat days occurred in 2015, when their number reached 21-22 days in Kłodzko, Długopole-Zdrój, and Lądek-Zdrój, and 15 days in Słoszów (Table 5). In this season, both July and August were characterized by the highest frequency of heat stress in the entire 1971-2020 period. In July, this varied from 5 days in Słoszów to 9 days in Kłodzko, while in August the number of such days amounted to 9 in Słoszów and 11-13 at the stations located lower down. 
Table 5. Annual frequency of heat days in the most extreme years in 1971-2020 in Kłodzko Land.

\begin{tabular}{ccccc}
\hline Year & Kłodzko & Długopole-Zdrój & Lądek-Zdrój & Słoszów \\
\hline 1992 & 11 & 12 & 12 & 7 \\
1994 & 13 & 13 & 13 & 9 \\
2013 & 10 & 10 & 10 & 7 \\
2015 & 21 & 22 & 22 & 15 \\
2018 & 11 & 13 & 9 & 6 \\
\hline
\end{tabular}

The results of the multiannual changes in the number of heat days in the discussed region indicated that the frequency of such weather conditions considerably increased over the last five decades. Regarding the tendency of the annual heat days frequency, positive and statistically significant trends were noticed for all of the stations (Figure 2, Table 6). The region of Długopole-Zdrój was characterized by the highest growth rate which amounted to 1 day per 7 years. In Kłodzko and Lądek-Zdrój, the increase reached about 1 day per 9 years, whereas in Słoszów, the growth was the lowest and amounted to 1 day per 14 years.
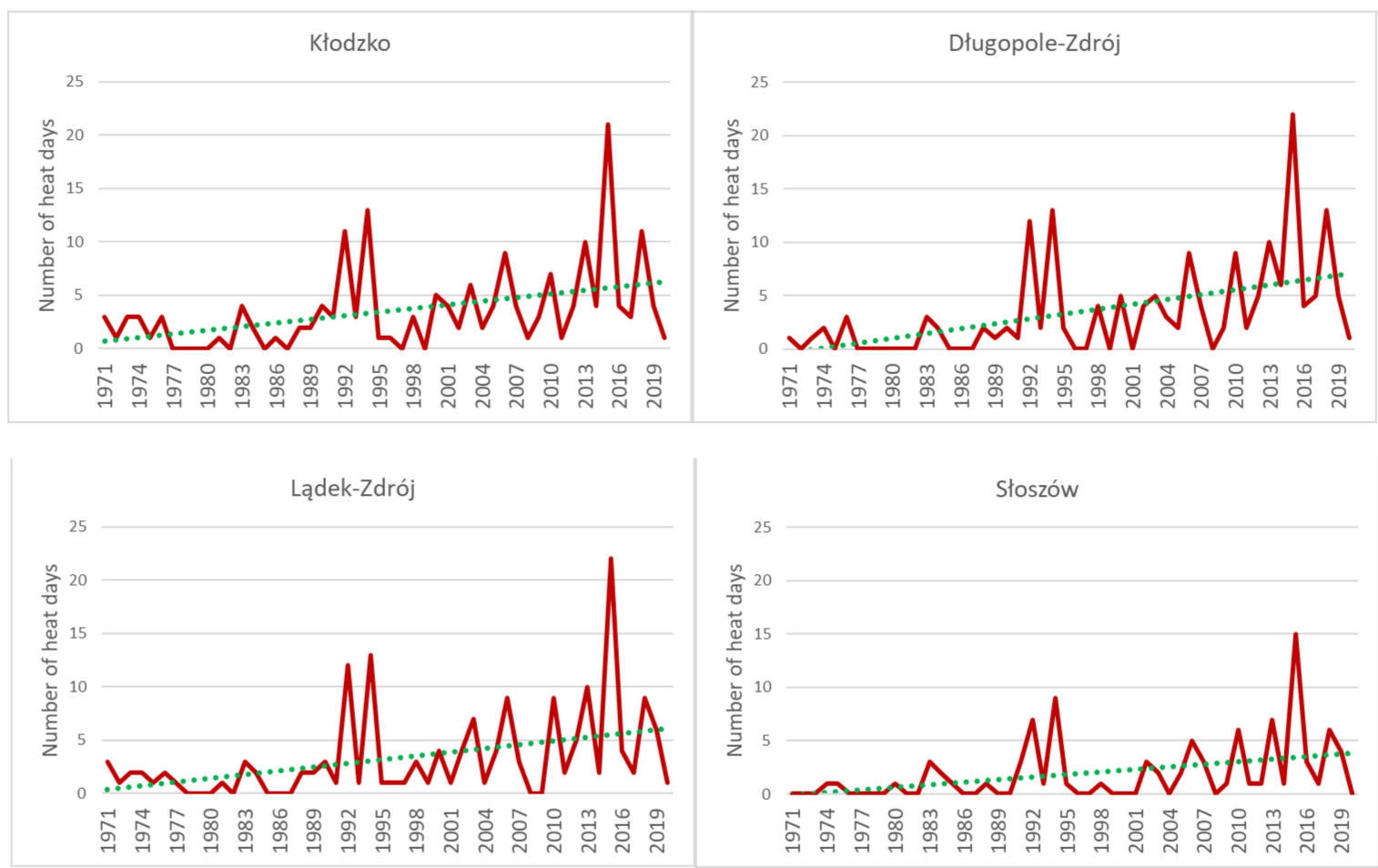

Figure 2. Annual number and linear trend of heat days $\left(\mathrm{T}_{\max }>30^{\circ} \mathrm{C}\right)$ in Kłodzko Land in 1971-2020.

Table 6. Rate of changes (per decade) in the number of heat days in July, August, and annually in 1971-2020 in Kłodzko Land (statistically significant trends at a level of 0.05 marked in bold).

\begin{tabular}{ccccc}
\hline Year & Kłodzko & Długopole-Zdrój & Lądek-Zdrój & Słoszów \\
\hline July & $\mathbf{0 . 5 0}$ & $\mathbf{0 . 6 3}$ & $\mathbf{0 . 4 7}$ & $\mathbf{0 . 3 2}$ \\
August & 0.48 & $\mathbf{0 . 5 6}$ & 0.44 & 0.32 \\
Annually & $\mathbf{1 . 1 1}$ & $\mathbf{1 . 4 8}$ & $\mathbf{1 . 1 5}$ & $\mathbf{0 . 7 2}$ \\
\hline
\end{tabular}

The rising tendency was also observed for July and August, when such weather conditions occurred the most frequently. In July, the number of heat days in DługopoleZdrój in 1971-2020 increased by more than 3 days. The growth in Kłodzko and Ladek-Zdrój exceeded 2 days, while Słoszów was the station with the lowest increase, reaching less than 2 days in the 50-year period. In August, a statistically significant trend at the level of 0.05 
was observed for Długopole-Zdrój only. In the case of the other stations, the trends were significant at a 0.1 level. The rate of increase in 1971-2020 was similar to the level observed in July-almost 3 days in Długopole-Zdrój, more than 2 days in Kłodzko and Ladek-Zdrój, and less than 2 days in Słoszów.

\subsection{Universal Thermal Climate Index (UTCI)}

Biothermal conditions, considering the impact of various meteorological variables, can be evaluated using the UTCI (Universal Thermal Climate Index). In the discussed period, mean annual UTCI varied from $6.6^{\circ} \mathrm{C}$ to $9.3^{\circ} \mathrm{C}$. These values, according to UTCI categories, indicated the classes of slight cold stress or no thermal stress. The annual course of mean monthly UTCI showed a relatively low variability between particular stations (Figure 3). Furthermore, the altitude in the discussed multiannual period was not the most significant factor affecting UTCI values. In this case, local wind conditions may have had an important impact on UTCI variability. Relatively high mean monthly UTCI at the stations located in the higher mountain zones (Lądek-Zdrój, Słoszów), especially in the wintertime, resulted mainly from lower wind speed if compared to the stations representing the bottom of the valley (Kłodzko, Długopole-Zdrój). The mean annual wind speed for 12:00 UTC in Lądek Zdrój was 1.1-1.3 m/s lower than in Długopole-Zdrój and Kłodzko. These two stations, due to their location in the main axis of the valley, were more often vulnerable to high-wind-speed conditions, because of wind being channeled between the surrounding mountain ridges. Mean monthly values of UTCI in the winter season at all of the stations varied from $-8{ }^{\circ} \mathrm{C}$ to $-2{ }^{\circ} \mathrm{C}$ and were equivalent to moderate cold stress. In summer, mean UTCI was equal to $18-20^{\circ} \mathrm{C}$ at the stations located lower down and $17-18^{\circ} \mathrm{C}$ in Słoszów. Thus, these values indicated no thermal-stress conditions.

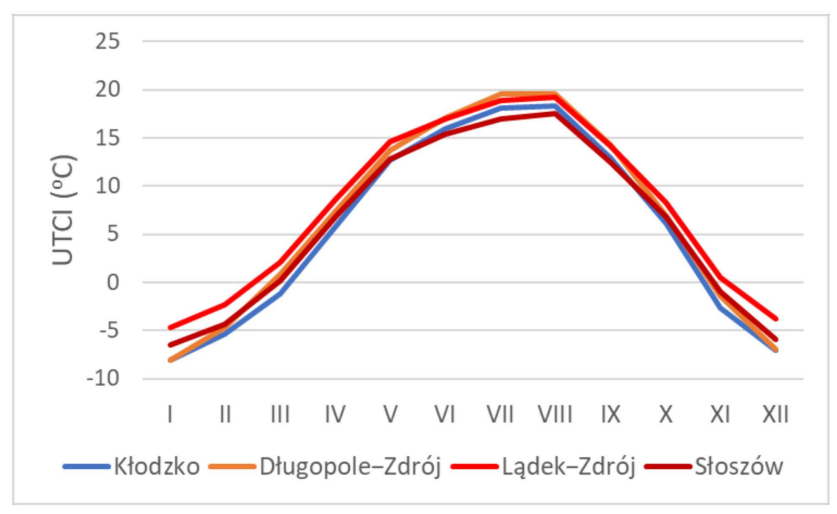

Figure 3. Mean monthly values of UTCI in 1971-2010 in Kłodzko Land, based on 12:00 UTC data.

In terms of UTCI categories, the class of no thermal stress in 1971-2010 prevailed at all of the stations. Its annual frequency varied at $38-42 \%$ and was the highest in the warm half-year, especially in May, June, and September (Figure 4). In these months, 68-74\% of days were characterized by thermoneutral conditions. In July and August, the frequency was lower due to a higher intensity of heat stress. During these months, the moderate heat stress class was frequent, reaching 25-31\%, while strong heat stress conditions were observed on $5-10 \%$ of days. In the higher hypsometric zones, represented by Słoszów, the number of days with heat stress was lower, and amounted to 23-24\% for moderate heat stress and $3-4 \%$ for strong heat stress. The class of very strong heat stress was noticed sporadically. Considering all the stations, moderate heat stress mainly occurred in the May-September period, while strong and very strong heat stress were usually noticed in the summer months. The category of extreme heat stress did not occur at all. 

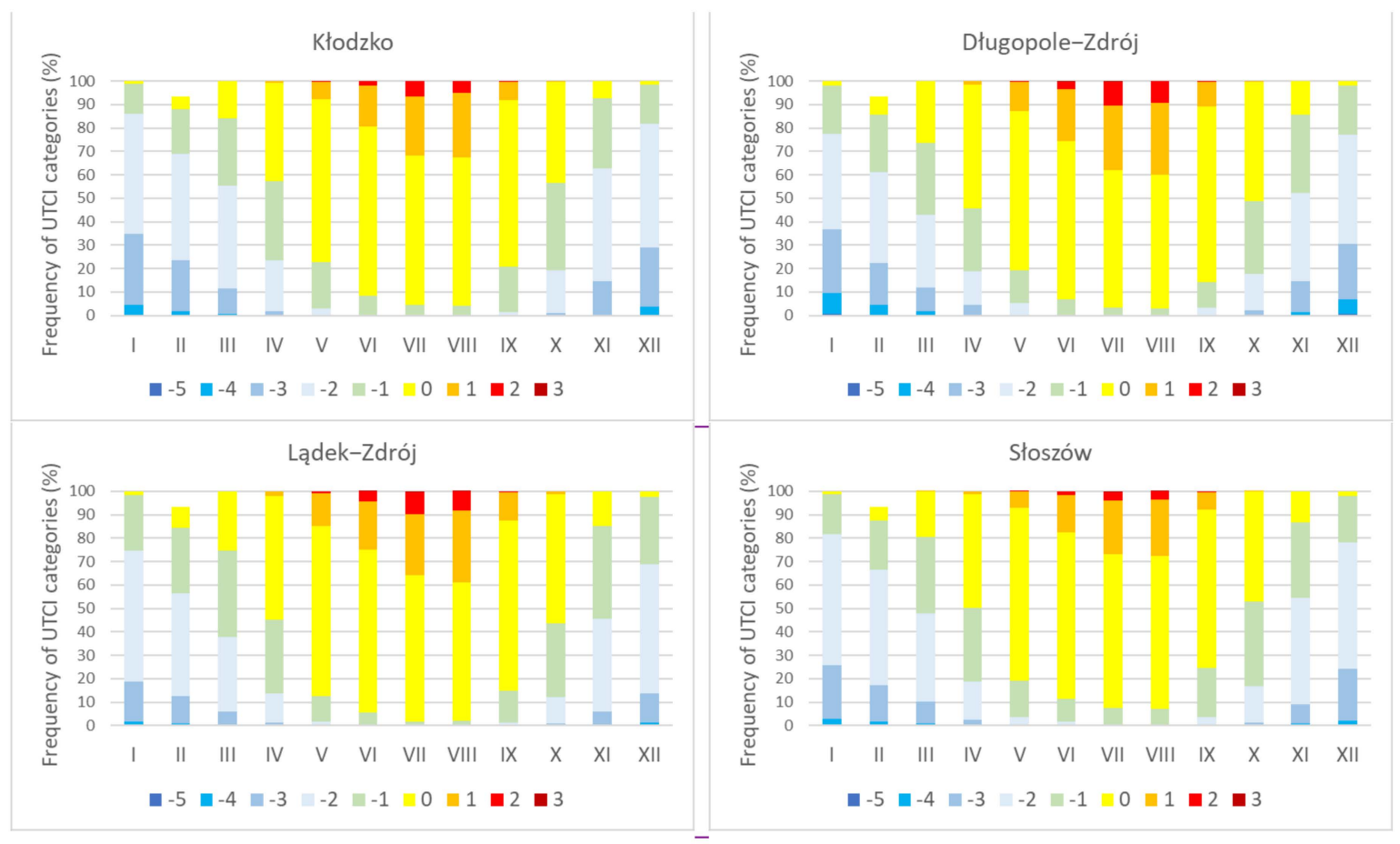

Figure 4. Frequency of UTCI categories in 1971-2010 in Kłodzko Land, based on 12:00 UTC data (UTCI categories: extreme cold stress (-5), very strong cold stress $(-4)$, strong cold stress $(-3)$, moderate cold stress $(-2)$, slight cold stress ( -1$)$, no thermal stress (0), moderate heat stress (1), strong heat stress (2), and very strong heat stress (3)).

Regarding cold stress, moderate and slight cold stress classes were observed most often. The annual frequency of days with these categories amounted to $20-24 \%$ for moderate cold stress and $19-21 \%$ for slight cold stress. It should also be emphasized that weather types related to these classes were observed throughout the year. However, moderate cold stress was usually noticed in winter months (39-56\% of days), while slight cold stress was the most frequent in the March-April and October-November periods, when the mean monthly number of days with such conditions varied at $27-40 \%$. A relatively high annual frequency was also noticed for strong cold stress (5-9\%). This category usually occurred in winter, especially in January, when $17-30 \%$ of days were characterized by such biothermal conditions. During the wintertime, the class of very strong cold stress was also observed. Its frequency for the entire winter season varied at 1-6\%. Extreme cold stress occurred sporadically in the winter months only.

The rising tendency of air temperature and the number of heat days had an impact on changes in UTCI in the multiannual period. Considering mean annual UTCI values, a positive trend was noticed for each of the stations. However, the statistical significance was observed only for Długopole-Zdrój and Ladek-Zdrój. In Długopole-Zdrój, the growth rate exceeded $1.2{ }^{\circ} \mathrm{C}$ per decade. In the case of Lądek-Zdrój, the increase was lower and amounted to about $0.5{ }^{\circ} \mathrm{C}$ per decade. The rising tendency of UTCI values caused an increase in the frequency of the categories characterized by the highest intensity of heat stress. In terms of the impact of heat stress on the human activity, weather conditions with a UTCI corresponding to strong and very strong heat stress $\left(\mathrm{UTCI}>32{ }^{\circ} \mathrm{C}\right.$ ) are very important. These types of biothermal conditions can be a serious risk for tourists and bathers visiting the discussed region. In the case of UTCI $>32{ }^{\circ} \mathrm{C}$, the positive trend with statistical significance at a level of 0.05 was noticed for Długopole-Zdrój. The rate of increase amounted to more than 2 days per decade (Figure 5). In Lądek-Zdrój, a positive tendency, characterized by statistical significance at a level of 0.1 , was observed. In this case, the combined number of days with strong and very strong heat stress increased at the rate of 1 day per decade. No statistically significant trends were noticed for Kłodzko and Słoszów. 


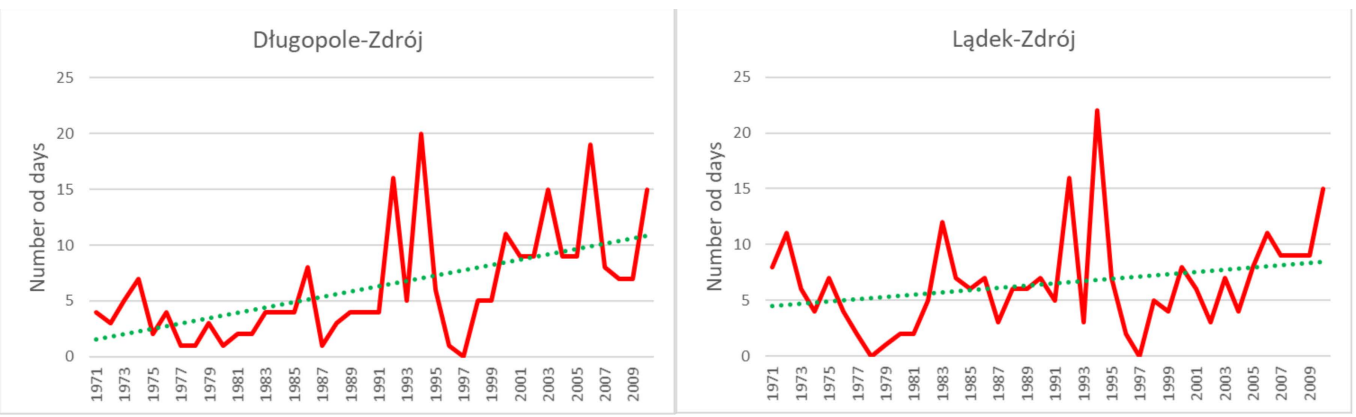

Figure 5. Annual number and linear trend of days with strong and very strong heat stress $\left(\mathrm{UTCI}>32{ }^{\circ} \mathrm{C}\right)$ in Długopole-Zdrój and Lądek-Zdrój in 1971-2010, based on 12:00 UTC data.

\subsection{Circulation Conditions and Their Impact on Heat Stress}

Biothermal conditions, including heat stress, usually strongly depend on atmospheric circulation. According to Ojrzyńska's classification [87], circulation conditions in the summer seasons (June-August) of 1971-2010 were characterized by a high frequency of anticyclonic types. In these terms, the type of SW-A was predominant, occurring on $30 \%$ of the days. In the case of NW-A and NE-A circulation, the frequency was equal to $23 \%$ and $16 \%$, respectively. The remaining anticyclonic types, SE-A and XX-A, occurred more rarely, during $4 \%$ and $2 \%$ of days. Regarding the cyclonic types, SW-C was the most frequent $(12 \%)$, while the occurrence of days with NE-C, NW-C, and SE-C varied at $3-5 \%$. The type of $\mathrm{XX}-\mathrm{C}$ was characterized by the lowest frequency, equal to $1 \%$ (Figure 6 ).

Heat stress in Kłodzko Land was usually noticed on days with SW-A and NE-A circulation (Table 7). They were one of the most frequently occurring types and were related to the advection of tropical and continental polar air masses from the south and east. In the summer seasons of $1971-2010$, SW-A was predominant, as $37-43 \%$ of days with UTCI $>32{ }^{\circ} \mathrm{C}$ were concerned with this type of circulation. The frequency for NE-A type amounted to $20-26 \%$, while the occurrence for the NW-A and SE-A was significantly lower and reached $10-12 \%$ and $8-9 \%$, respectively. On the other hand, heat stress during cyclonic types of weather occurred more rarely because of lower air temperature, higher wind speed, and worse solar conditions. In this case, the type of SW-C was characterized by the highest frequency reaching $4-12 \%$.

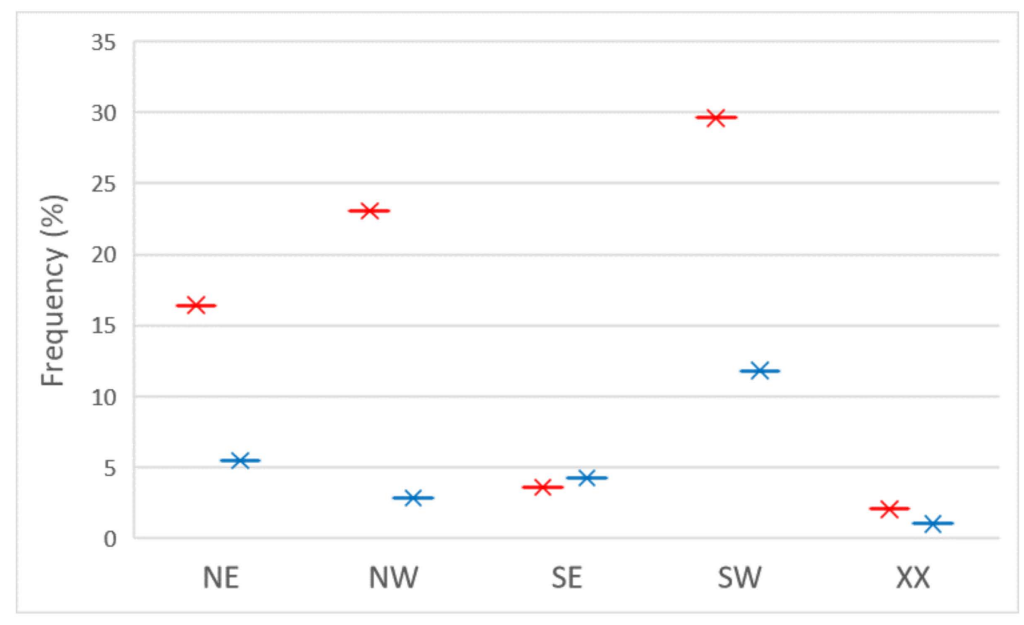

Figure 6. Frequency of anticyclonic (red) and cyclonic (blue) types of circulation in Kłodzko Land in the summer seasons (June-August) of the 1971-2010 period, based on H. Ojrzyńska's classification [87]. 
Table 7. Frequency of days (\%) with UTCI $>32{ }^{\circ} \mathrm{C}$ (June-August) under particular types of circulation in Kłodzko Land in 1971-2010, based on 12:00 UTC data.

\begin{tabular}{cccccccccccc}
\hline Station & NE-A & NE-C & NW-A & NW-C & SE-A & SE-C & SW-A & SW-C & XX-A & XX-C & Total \\
\hline Kłodzko & 25.7 & 1.2 & 10.8 & 0.0 & 8.4 & 1.2 & 41.9 & 4.2 & 5.4 & 1.2 & 100.0 \\
Długople-Zdrój & 20.3 & 0.4 & 10.1 & 0.4 & 7.6 & 1.7 & 42.6 & 10.5 & 5.1 & 1.3 & 100.0 \\
Ladek-Zdrój & 21.8 & 0.8 & 10.9 & 0.4 & 9.3 & 2.8 & 38.3 & 9.3 & 4.8 & 1.6 & 100.0 \\
Słoszów & 26.1 & 1.7 & 12.2 & 0.0 & 8.7 & 0.9 & 36.5 & 12.2 & 0.9 & 0.9 & 100.0 \\
\hline
\end{tabular}

Considering the percentage of days with UTCI $>32{ }^{\circ} \mathrm{C}$ under particular types of circulation, the structure of heat-stress occurrence was different, mainly in favor of the higher frequency of SE-A and XX-A types (Table 8). More than 10-17\% of days with SE-A circulation at the stations located lower down and almost $8 \%$ of days in Słoszów were characterized by strong or very strong heat-stress presence. In the lower hypsometric zones, a very high fraction was also observed for the XX-A circulation. This type was mainly related to the centre of a high-pressure system located over the region. However, both SE-A and XX-A types, in the summer seasons of 1971-2010, occurred with a relatively low frequency. As a result, the total number of days with UTCI $>32{ }^{\circ} \mathrm{C}$ under such circulation conditions was significantly lower than in the case of the more-frequent types, such as SW-A or NE-A.

Table 8. Percentage of heat days and days with UTCI $>32{ }^{\circ} \mathrm{C}$ among the total number of days with particular types of circulation for 1971-2010, based on 12:00 UTC data.

\begin{tabular}{ccccccccccc}
\hline Station & NE-A & NE-C & NW-A & NW-C & SE-A & SE-C & SW-A & SW-C & XX-A & XX-C \\
\hline Kłodzko & 7.1 & 1.0 & 2.1 & 0.0 & 10.7 & 1.3 & 6.4 & 1.6 & 12.0 & 5.4 \\
Długople-Zdrój & 7.9 & 0.5 & 2.8 & 1.0 & 13.7 & 2.6 & 9.3 & 5.8 & 16.0 & 8.1 \\
Lądek-Zdrój & 8.9 & 1.0 & 3.2 & 1.0 & 17.6 & 4.5 & 8.7 & 5.3 & 16.0 & 10.8 \\
Słoszów & 5.0 & 1.0 & 1.6 & 0.0 & 7.6 & 0.6 & 3.9 & 3.2 & 1.3 & 2.7 \\
\hline
\end{tabular}

In the context of changes in the frequency of days with strong and very strong heat stress depending on the circulation types, most of the trends for the summer seasons of 1971-2010 were not statistically significant. The most noticeable changes were observed for the types characterized by a high frequency-NW-A, SW-A, and SW-C. The changes in the number of days with UTCI $>32{ }^{\circ} \mathrm{C}$ in this period for some of the stations were characterized by positive and statistically significant trends (Table 9). Długopole-Zdrój was the station with the most considerable changes. The highest increase was observed for the types that occurred frequently-SW-A and SW-C. The rate of changes for the SW-A type exceeded 1 day per decade, while for SW-C, the growth was less intensive, and amounted to 1 day per 17 years (Figure 7). A statistically significant positive trend was also observed for the XX-A type. However, this type of circulation occurred more rarely than SW-A and SW-C. The second station with statistically significant trends was Lądek-Zdrój. In this case, such a tendency was observed for the NW-A and SW-C circulation. The growth rate amounted to 1 day per 24 years and 1 day per 26 years, respectively. Furthermore, a positive trend, characterized by statistical significance at a level of 0.1 , was noticed for the NE-A and NW-A types in Długopole-Zdrój. In this case, the rate of increase reached 1 day per 20/30 years.

Table 9. Changes (days per decade) in the number of days with UTCI $>32{ }^{\circ} \mathrm{C}$ under particular types of circulation in the summer seasons of 1971-2010 in Kłodzko Land (statistically significant trends marked in bold).

\begin{tabular}{ccccccccccc}
\hline Station & NE-A & NE-C & NW-A & NW-C & SE-A & SE-C & SW-A & SW-C & XX-A & XX-C \\
\hline Kłodzko & 0.20 & 0.00 & 0.24 & 0.00 & 0.03 & 0.61 & 0.51 & 0.10 & 0.09 & 0.00 \\
Długople-Zdrój & 0.51 & 0.01 & 0.34 & 0.03 & 0.21 & 0.05 & $\mathbf{1 . 0 7}$ & $\mathbf{0 . 5 9}$ & $\mathbf{0 . 2 0}$ & 0.04 \\
Lądek-Zdrój & 0.01 & 0.01 & $\mathbf{0 . 4 1}$ & 0.03 & -0.2 & 0.02 & 0.39 & $\mathbf{0 . 3 8}$ & 0.02 & 0.01 \\
Słoszów & -0.01 & -0.01 & 0.03 & 0.00 & -0.04 & 0.00 & -0.08 & 0.16 & 0.04 & 0.01 \\
\hline
\end{tabular}



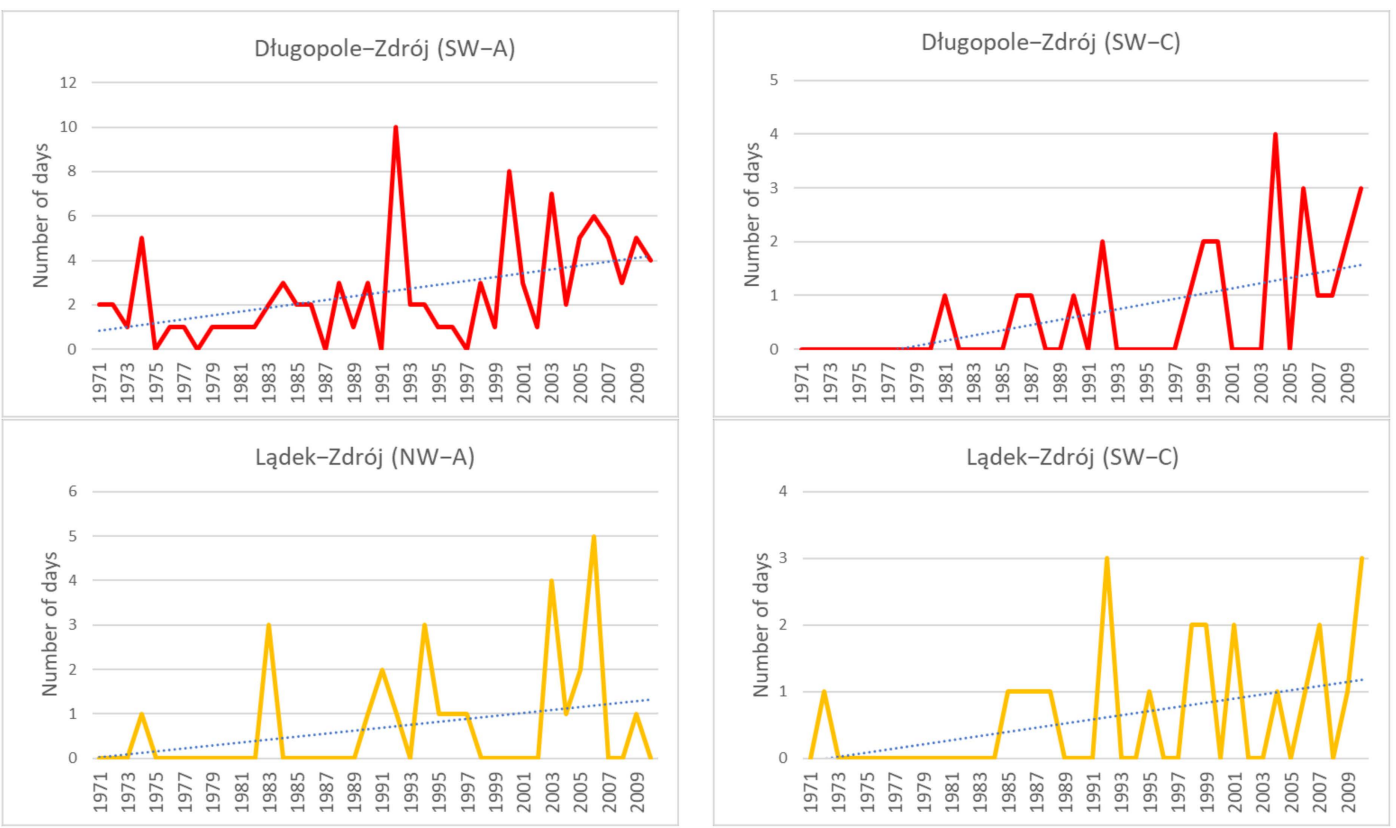

Figure 7. Changes in the number of days with UTCI $>32{ }^{\circ} \mathrm{C}$ in Długopole-Zdrój under SW-A and SW-C circulation (top) and in Lądek-Zdrój under NW-A and SW-C circulation (bottom) in 1971-2010.

\subsection{Climate Tourism Information Scheme (CTIS)}

Climate-tourism conditions, based on CTIS (Climate Tourism Information Scheme) criteria, depend on both biothermal conditions and the influence of various meteorological variables. In the context of thermal comfort, defined as no thermal stress or slight cold stress according to the UTCI, the most favourable conditions in 1971-2010 in the entire region were observed in spring and autumn (Figures 8-11). This mainly concerned the last decade of April, May, and the turn of September and October, when the frequency of days with thermal comfort often exceeded $90 \%$. In the summer season, the occurrence was lower because of a higher intensity of heat stress. The number of days with moderate, strong, or very strong heat stress in late July and early August could reach as much as $40 \%$ of the total number of days in these periods. The frequency of thermal comfort was also significantly lower in the cold half-year, especially in the winter months. This could fall down to ca. $10-20 \%$ in the beginning of January in favor of the increased frequency of cold stress. In this period, due to low values of air temperature, high wind speed, and worse solar conditions, the classes of the most intensive cold-stress categories can occur on more than $80 \%$ of days.

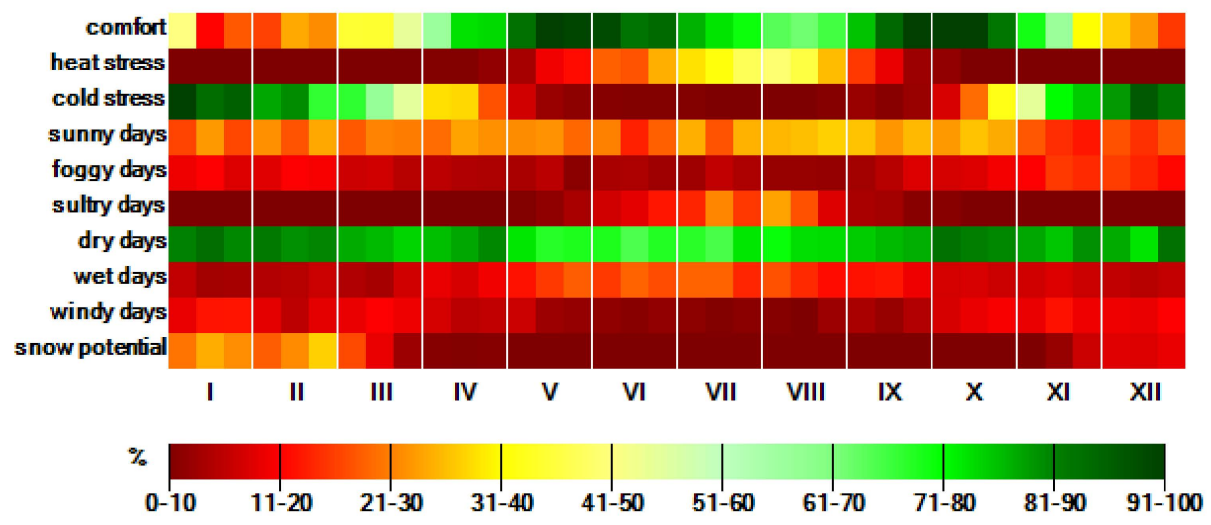

Figure 8. CTIS for Kłodzko in 1971-2010. 


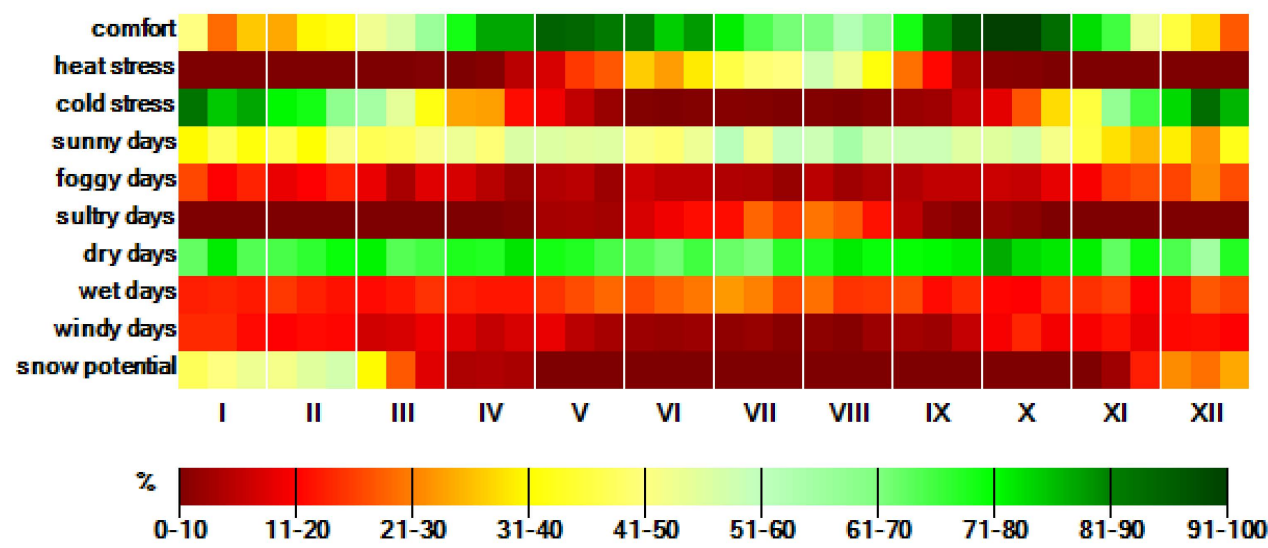

Figure 9. CTIS for Długopole-Zdrój in 1971-2010.

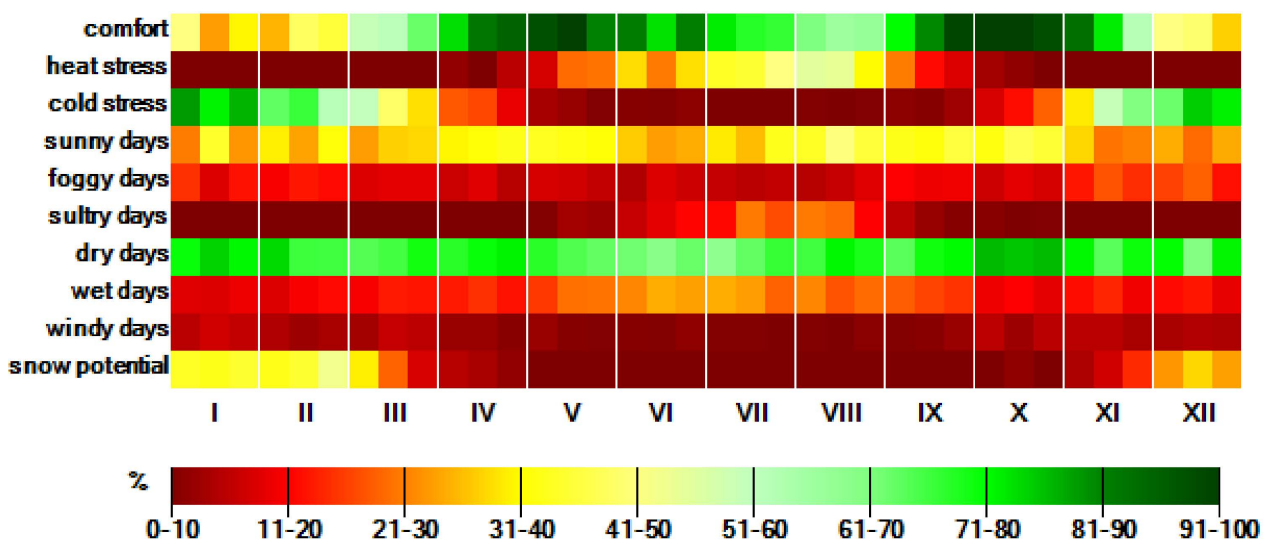

Figure 10. CTIS for Lądek-Zdrój in 1971-2010.

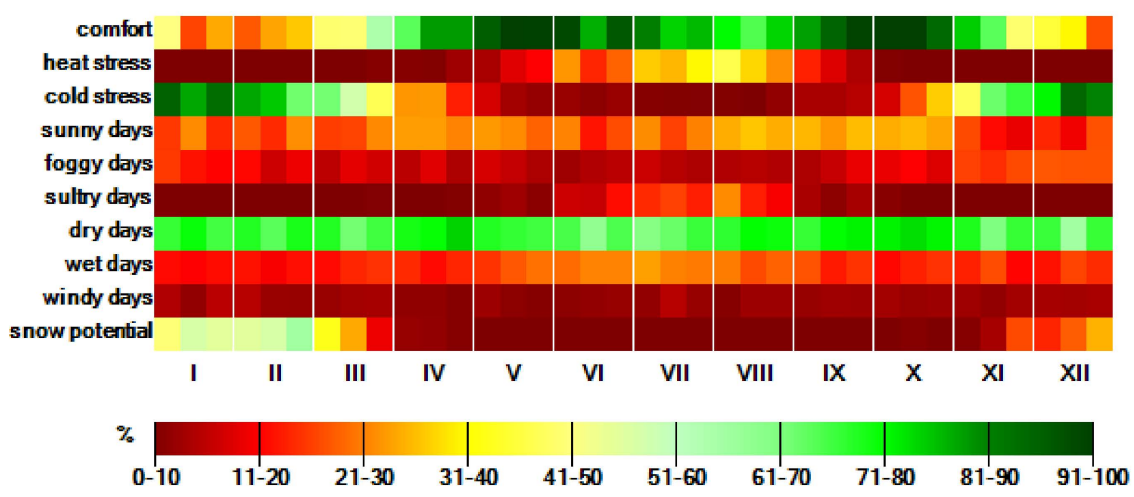

Figure 11. CTIS for Słoszów in 1971-2010.

In terms of the meteorological variables considered in the study, the most favourable solar conditions were mainly noticed in the warm half-year, especially from the third decade of July until the middle of October, when they usually occurred with a frequency of $20-50 \%$. In June, an increased intensity of cyclonic circulation, related to the higher cloudiness, limited the number of sunny days in the region. The lowest number of sunny days was observed in the wintertime and November.

One of the most important factors affecting both tourism and human health was weather conditions characterized by very high (>93\%) relative humidity, which can result in fog appearance. Such situations usually occurred in winter and November, when their frequency could exceed $15 \%$. On the other hand, the number of foggy days was very low 
in the summertime, when relative humidity exceeding $93 \%$ was observed on less than $6 \%$ of days.

In the case of sultry days, they usually occurred from May to October, with the highest intensity in the summer season. This especially concerned the first decade of August. In this period, about $19-21 \%$ of days were considered as sultry, and consequently negatively affected human health and outdoor recreation. In the cold half-year, sultry days were not observed or occurred sporadically.

The tourism activities can be also limited by precipitations. Weather conditions without precipitation or with daily totals reaching up to $1 \mathrm{~mm}$ were the most frequent in the wintertime and October, when they could occur on more than $80 \%$ of days. In these terms, the highest number of dry days was noticed in the area located at the lowest altitude, represented by the station of Kłodzko. The mean difference between Kłodzko and the other stations amounted to $8-9 \%$.

Intensive precipitation with daily totals of more than $5 \mathrm{~mm}$ were typical for the warm half-year and occurred the most frequently in June and July. These summer months are considered to be very popular from the tourism perspective. Therefore, the aspect of limiting tourism activity by strong precipitations is significant in that case. The number of wet days in the higher hypsometric zones could exceed as much as $20 \%$ of all days in this period.

Strong wind has a negative influence on human heat balance and limits some tourism activities. Days with wind speed higher than $8 \mathrm{~m} / \mathrm{s}$ were the most frequent in the cold halfyear. The stations located in the bottom of the Kłodzko Valley (Kłodzko, Długopole-Zdrój) were characterized by the highest frequency of windy days, exceeding $10 \%$. Such values were also noticed in the third decade of October and November. A lower number of windy days was observed at the stations located at the higher altitude. In this case, the frequency did not reach $6 \%$.

Snow potential plays a very important role in Kłodzko Land, because of a very high importance of this region for winter recreation. The best snow conditions were observed in the higher hypsometric zones, represented by Słoszów. The third decade of February was the most favourable period for skiing. The frequency of snow cover depth (more than 10 $\mathrm{cm}$ ) was equal to $55 \%$, while from the second decade of January until the second decade of February, it amounted to $44-46 \%$. Moderately favourable snow conditions were observed in the middle of March, when the frequency of snow cover still exceeded $20 \%$. On the other hand, the worst snow potential was noticed in Kłodzko, where snow cover occurred with the frequency of $21-26 \%$ in the two final decades of January and in the second and third decade of February.

Favourability of weather conditions for tourism is different depending on atmospheric circulation. Comparing the CTIS results for the anticyclonic and cyclonic circulation types, differences were observed for all of the categories of thermal stress and for the considered meteorological variables. In terms of thermal comfort, the highest anomalies in favor of the anticyclonic circulation were noticed in the cold season (Figures 12-15). In the case of the stations located lower down, the differences in the number of days with thermal comfort could reach as much as $15-20 \%$. Such a situation was mainly contributed by worse solar, humidity, and wind conditions during the cyclonic types of weather. On the other hand, the cyclonic circulation was often more favourable in the summertime, because of lower air temperature that contributed to the reduction of heat stress. As a result, the anticyclonic types of circulation in summer were characterized by a significantly higher frequency of heat stress. In some of the decades, the difference between the both types exceeded $15 \%$. The lowest differences, if compared to the other stations, were noticed in Słoszów. Because of the location of the station outside the windy Kłodzko Valley and lower air temperature in the summertime, the station was characterized by lower anomalies for both thermal comfort and heat stress. Cold stress, due to lower air temperature, higher wind speed, and worse solar conditions, occurred more often under the cyclonic circulation. 

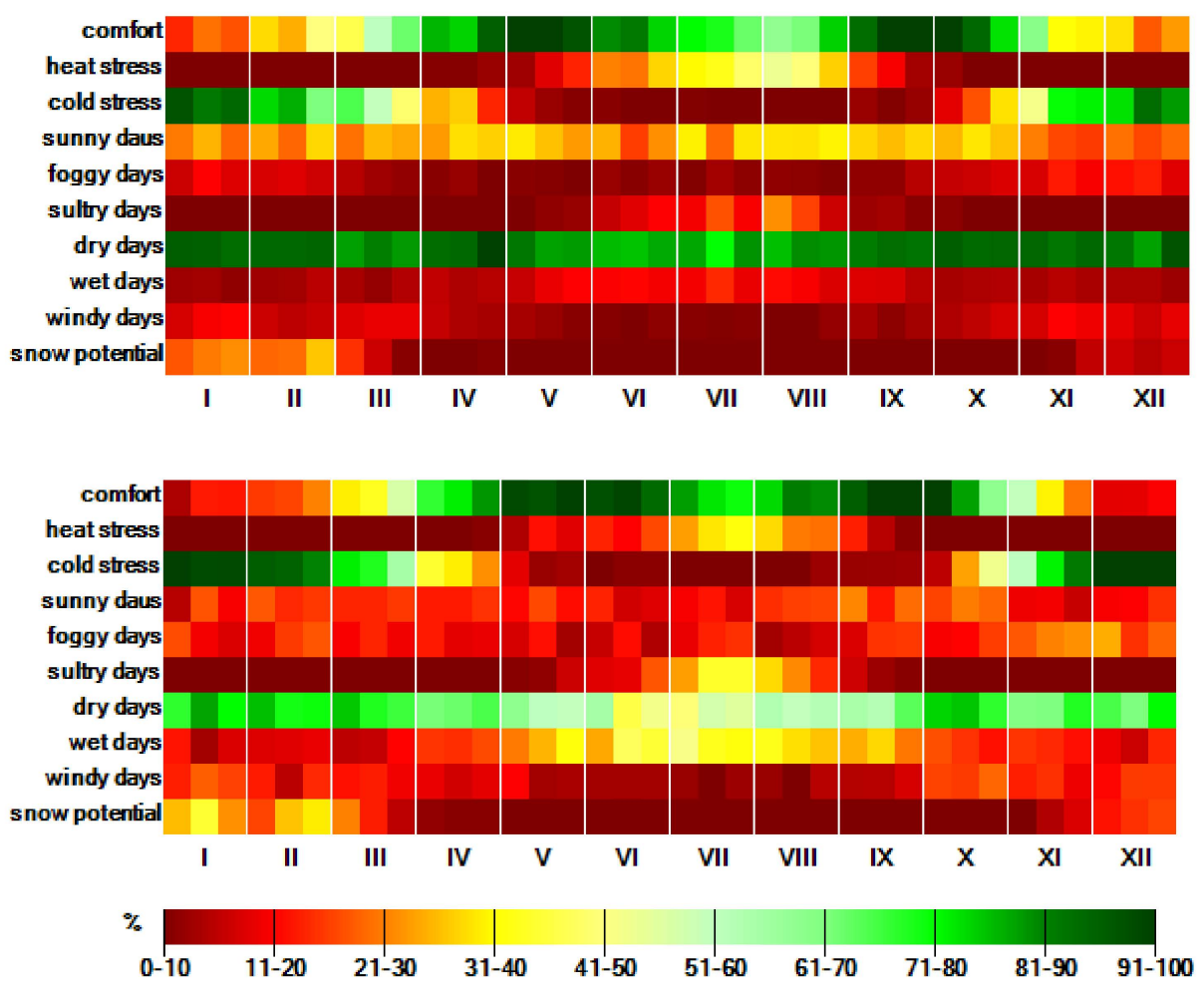

Figure 12. CTIS in Kłodzko for anticyclonic (top) and cyclonic (bottom) types of circulation in 1971-2010.
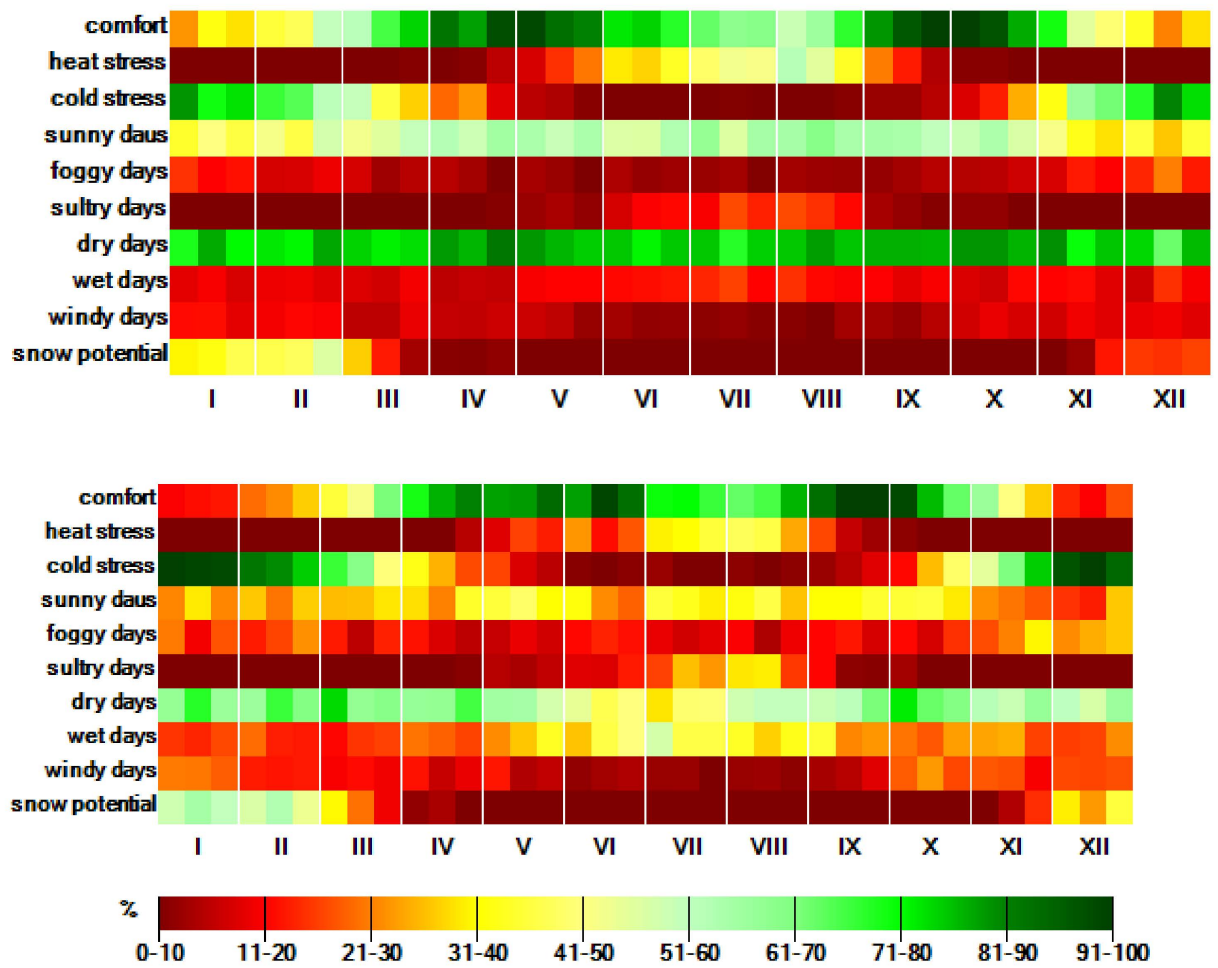

Figure 13. CTIS in Długople-Zdrój for anticyclonic (top) and cyclonic (bottom) types of circulation in 1971-2010. 

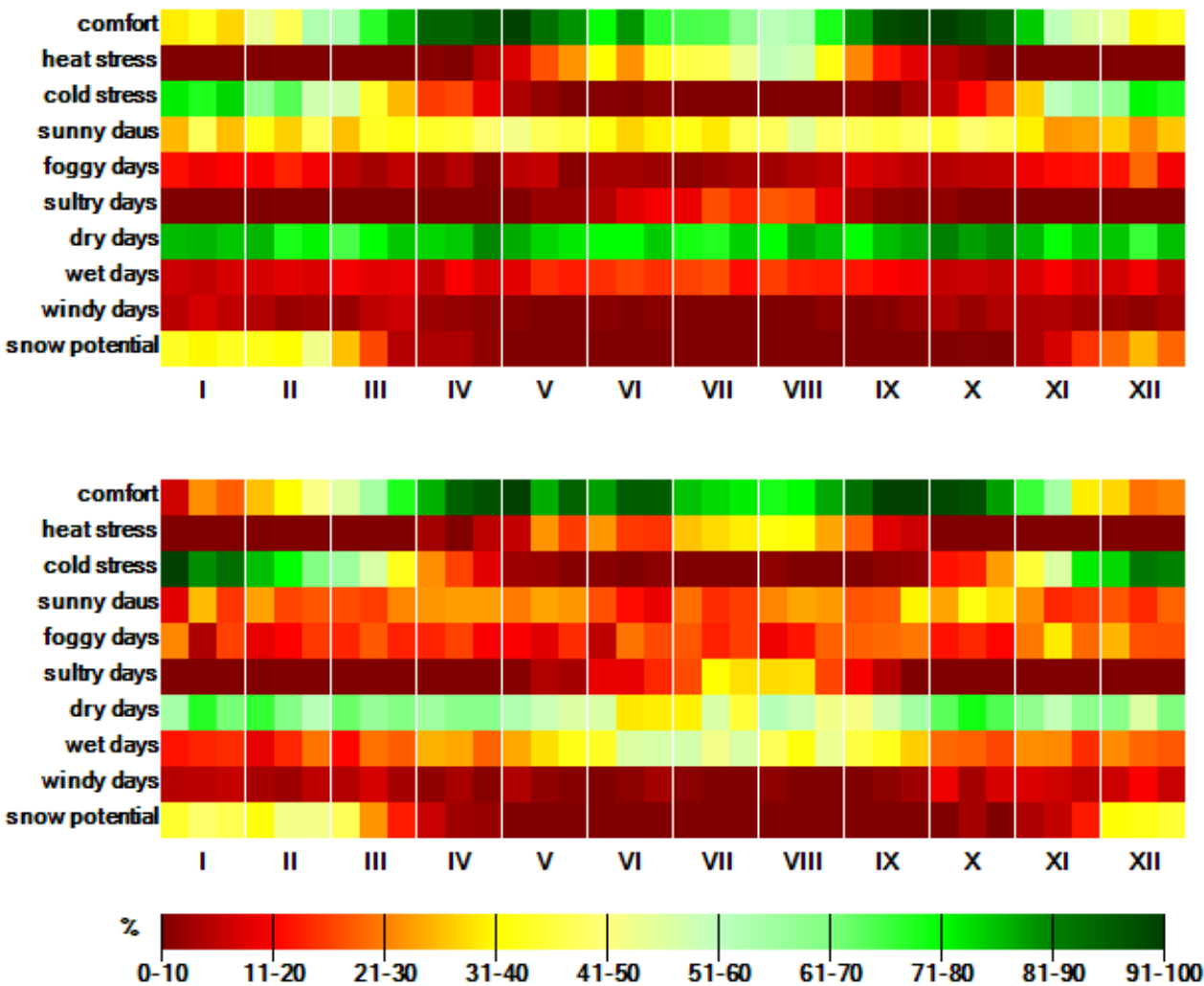

Figure 14. CTIS in Lądek-Zdrój for anticyclonic (top) and cyclonic (bottom) types of circulation in 1971-2010.
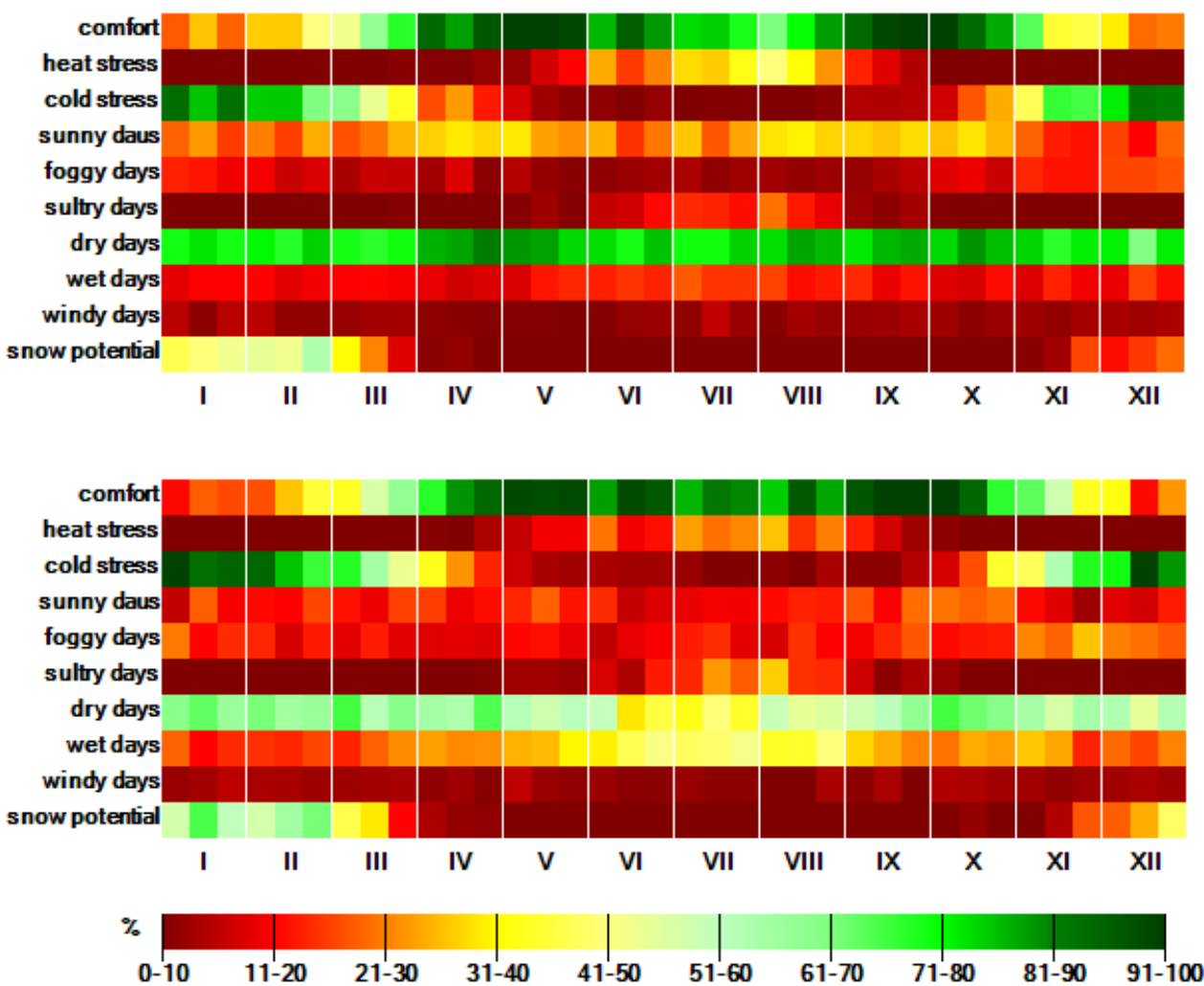

Figure 15. CTIS in Słoszów for anticyclonic (top) and cyclonic (bottom) types of circulation in 1971-2010. 
In the case of sunny and foggy days, weather types related to the anticyclonic circulation were characterized by more-favourable conditions. The frequency of sunny days was higher under the anticyclonic types throughout the year, with the differences varying from $5-15 \%$ in winter to $15-30 \%$ in some decades of the summer months. The days with high relative humidity, often resulting in fog presence, occurred more often under the cyclonic circulation. The highest anomalies between the both types were noticed in late November, when they could reach $20 \%$. Sultry days, because of higher humidity, were typical for the cyclonic circulation. In July and August, the frequency of such weather conditions in the lower hypsometric zones was about $15-20 \%$ higher than under anticyclonic circulation. In Słoszów, the difference was minor, and amounted to 7\%. In the case of precipitation conditions, the anticyclonic types of weather were more favourable throughout the year in terms of both dry and wet days indices. The most significant anomalies were noticed in the warm half-year, especially in the summer season. The number of dry days during the anticyclonic circulation at the turn of June and July was up to $45 \%$ higher than for the cyclonic types. Regarding the intensive precipitations, they also occurred more frequently under the cyclonic weather. The differences between the both types in the summer months reached up to 30-35\%. In the case of wind conditions, the cyclonic weather was usually characterized by a higher number of windy days. This concerns especially the cold season and the stations located in the bottom of the Kłodzko Valley, where high wind speed is a crucial factor. In Kłodzko and Długopole-Zdrój, the frequency of strong wind in October under cyclonic circulation was more than $10 \%$ higher than for the anticyclonic types. The anomalies equal to 8-9\% were also noticed in January. Snow potential was characterized by more useful conditions for skiing during the cyclonic types of weather. In these terms, the most-significant differences, reaching up to $25 \%$ in the second decade of January, were noticed in Słoszów, where the frequency of snow cover was the highest.

\section{Discussion and Conclusions}

The results presented in the study indicate that the region of Kłodzko Land is characterized by a significant temporal variability of climate conditions in the context of their influence on health and tourism issues. The research showed that one of the most important weather factors is heat stress, for which a rising tendency was observed for both indices-heat days and UTCI. The mean frequency of heat days in the lower hypsometric zones amounted to more than 3 days a year, which was comparable to the number observed in the lower mountain zone of the Western Sudety [68], the Silesian Foothills (southern Poland) [84], and in the coastal regions of Germany and Poland [22,24,88]. The multiannual changes indicated that heat-stress frequency has significantly risen over the last decades and can intensify in the following years. The rate of increase in the annual number of heat days varied from 1 day per 7 years to 1 day per 14 years. Thus, this growth was comparable to the lowland regions of Poland, especially Greater Poland (Wielkopolska), where the rate for 1951-2006 differed from 1 day per 8 years to 1 day per 15 years [24]. The increase reaching at least 1 day per decade was also noticed for most of the lowlands and the lower mountains zones in Poland in 1951-1915 [88]. In the regions located lower down, the changes in heat-day frequency were also lower or comparable to the Western Sudetes [58]. In Słoszów, where the intensity of changes was the lowest, the rate was similar to the northern parts of Poland [88]. On the other hand, the increase for the stations located in Kłodzko Land was noticeably lower if compared to the lowland part of the Lower Silesia, where the frequency of heat days in 1971-2019 rose at the rate of more than 2 days per decade [68].

Regarding UTCI, the structure of its categories in the warm season was characterized by the highest number of days with no thermal stress and higher frequency of moderate and strong heat stress in the summer months. The class of very strong heat stress was observed occasionally, while extreme heat stress did not occur at all. In the cold season, slight, moderate, and strong cold-stress categories were predominant. Similar conditions are typical for the regions located in the lowlands and the lower mountain zones of Poland 
and Central Europe $[10,23,48,50,51,53,54,66-69,89-91]$. The analysis carried out in the paper showed that the frequency of moderate heat stress in July and August in the lower hypsometric zones of Kłodzko Land was about 5\% lower than in the Carpathian region, confirming the results of the previous studies [48]. Simultaneously, the number of days with strong and very strong heat stress (UTCI $>32{ }^{\circ} \mathrm{C}$ ) was comparable to the lowlands of the Lower Silesia [56] and the lower zones of the Western Sudetes Mountains $[68,69]$. Such similarities were also noticed for cold-stress categories. However, it should be emphasized that the highest parts of the Sudetes Mountains are characterized by a very high number of days with extreme cold stress and no heat stress occurrence [52,67-69]. In the discussed region, such conditions may be observed in the summit zone of the Śnieżnik Massif and the Bystrzyckie Mountains, which are the highest ridges in Kłodzko Land. Nevertheless, the health resorts and most of the tourism objects of the region are located at a relatively low altitude. Therefore, the intensity of heat stress and its influence on both health and tourism issues seems to be more significant than the impact of cold stress conditions. In the urban areas, the intensity of heat stress can even locally reach beyond $46^{\circ} \mathrm{C}$, which is the equivalent to the extreme heat stress category [70].

Changes in the mean annual UTCI values amounted to $0.5-1.2^{\circ} \mathrm{C}$ per decade, and were similar or higher if compared to the trends for the western parts of the Sudetes Mountains [68], the Baltic Sea region [63], and Hungary [55]. Such a tendency contributed to the increase in the frequency of biothermal conditions with UTCI $>32{ }^{\circ} \mathrm{C}$, corresponding to strong and very strong heat stress. They negatively affected persons with cardiovascular diseases $[23,47,65]$ and seriously limited tourism, especially in urban areas [92]. The intensity of changes in the number of days with UTCI $>32{ }^{\circ} \mathrm{C}$ in 1971-2010 in the health resort of Długopole-Zdrój exceeded 2 days per decade, and was comparable to the observed for the Baltic Sea region in 1981-2010 [53] and south and southeast Poland in 1966-2015 [42]. In these regions, the rate of growth amounted to 2 or more days per decade. Simultaneously, the increase in the frequency of strong and very strong heat stress in Ladek-Zdrój, reaching up to 1 day per decade, was similar to the rate observed for Warsaw [52] and Jelenia Góra (lower zones of the Western Sudetes Mountains) [68]. Regarding circulation conditions, the classification tailored exactly for the considered region was used. This enabled detailed analysis concerning the impact of the local circulation on bioclimate conditions, especially heat stress. According to Ojrzyńska's classification, most of strong and very strong heat stress cases occurred under SW-A and NE-A circulation types, and were mainly related to the advection of tropical and continental polar air masses. The advections from these directions often contribute to heat-stress presence in Central Europe $[49,50,52-54,64,67,68]$. Considering the percentage of days with UTCI $>32{ }^{\circ} \mathrm{C}$ under particular circulation conditions, the XX-A and SE-A types were characterized by a very high fraction of strong and very strong heat stress. A similar situation was observed in Germany [62] and the western part of Lower Silesia [68]. In these cases, the highest number of days with UTCI $>32{ }^{\circ} \mathrm{C}$ was noticed during the anticyclonic circulation of SW, while the SE-A type was characterized by a very high percentage of such days. The anticyclonic types of SW and SE were also significant in shaping heat-stress conditions in eastern Poland [50]. In the northern Carpathians, the southern anticyclonic circulation was responsible for one of the highest values of UTCI [93].

Similarly to the Polish-Saxon border region, the most noticeable changes in the heatstress frequency in Kłodzko Land in 1971-2010 were noticed for SW-A, SW-C, and NW-A types. The maximum intensity of growth reached up to 1 day per decade, 1 day per 17 years, and 1 day per 24 years, respectively, exceeding the rates for the western part of Lower Silesia and eastern Saxony [68]. It should also be emphasized that the projected changes in these types of circulation for Germany indicate a further increase in the frequency of strong and very strong heat stress in the future [62]. Thus, the heat-stress conditions related to these circulation types can be significantly intensified in the following years in the region of Central Europe.

The atmospheric circulation also defines the favourability of weather conditions for tourism and recreation, according to the CTIS criteria. The anticyclonic types of circulation 
contributed to the increase in thermal comfort in the cold season, while the cyclonic weather limited the intensity of heat stress in the summertime. Generally, the most favourable biothermal conditions in terms of CTIS were noticed in spring and autumn. Similar results (using different biothermal indices) were carried out for the lowlands and the lower mountain zones of Austria, Germany, and Romania [5,72,78]. Simultaneously, the annual structure of biothermal conditions is different from the highest mountain zones, where the summertime is the optimal period for tourism $[69,71,72,74,81]$. In the case of the criteria defined by meteorological variables, the region of Kłodzko Land was characterized by relatively favourable conditions concerning humidity, wind speed, and precipitations. Comparably to the lower mountain zones of the Western Sudetes Mountains, at least 60\% of days throughout the year were usually characterized by weather conditions useful for tourism purposes [69]. Both regions were also similar to each other in terms of solar conditions. In the warm season, the frequency of sunny days in Kłodzko Land was equal to 20-50\%, while in the Western Sudetes it amounted to 30-50\% [69]. A comparable number of sunny days was also noticed in the lower alpine zones [72]. Kłodzko Land was also more favourable in the case of wind criterion in the comparison to the coastal area of Poland, where wind speed exceeding $8 \mathrm{~m} / \mathrm{s}$ occurred on $14-36 \%$ of days [80]. Snow conditions for skiing were similar to the observed for the lower parts of the other Polish and European mountains $[69,72,74,81]$ and worse than in the higher hypsometric zones $[69,71,72,74,81]$. However, it should be remembered that geographical variability of Kłodzko Land can contribute to a significant differentiation in snow-cover conditions. The mean duration of snow cover in the hypsometric profile of the Sudety Mountains increases more than 8 days per $100 \mathrm{~m}$ [94].

The results presented in the study showed that Kłodzko Land is characterized by relatively favourable climate conditions for tourism and climatotherapy. However, the region is also vulnerable to heat stress, the frequency of which has significantly increased over the last decades. The projections of biothermal conditions indicate that heat stress can be additionally intensified in the future in this part of Europe $[62,82,95,96]$. Therefore, appropriate adaptation measures should be undertaken to prevent tourist and bathers from the negative influence of heat-related weather. It should also be emphasized that biothermal conditions, including heat stress, can significantly vary in this region depending on altitude, exposition, terrain relief, vegetation, and other geographical factors [70]. The results of this study can contribute to expand the knowledge of climate and bioclimate conditions of the discussed region. They can also be used in tourism planning and serve as supplementary information for health resorts.

Funding: This research received no external funding.

Institutional Review Board Statement: Not applicable.

Informed Consent Statement: Not applicable.

Data Availability Statement: Not applicable.

Acknowledgments: The author would like to thank Hanna Ojrzyńska (University of Wrocław) for providing the calendar of synoptic conditions for the Sudetes Mountains.

Conflicts of Interest: The authors declare no conflict of interest.

\section{References}

1. Mieczkowski, Z. The Tourism Climate Index: A Method of Evaluating World Climates for Tourism. Can. Geogr. 1985, 29, 194-288. [CrossRef]

2. Błażejczyk, K. Bioklimatyczne uwarunkowania rekreacji i turystyki w Polsce (Bioclimatic principles of recreation and tourism in Poland). IGIPZ-PAN Pr. Geogr. 2004, 192, 291.

3. Matzarakis, A. Assessment method for climate and tourism based on daily data. In Developments in Tourism Climatology; Matzarakis, A., de Freitas, C.R., Scott, D., Eds.; Commission Climate, Tourism and Recreation, International Society of Biometeorology: Freiburg, Germany, 2007; pp. 52-58. 
4. Matzarakis, A.; Koch, E.; Rudel, E. Analysis on summer tourism period for Austria based on climate variables on daily basis. In Developments in Tourism Climatology; Matzarakis, A., de Freitas, C.R., Scott, D., Eds.; Commission Climate, Tourism and Recreation, International Society of Biometeorology: Freiburg, Germany, 2007; pp. 122-128.

5. Matzarakis, A. Assessment of Weather and Climate for Tourism and Health in the Alps. In Proceedings of the Metropolises and “Their" Alps. Forum Alpinum, Bayerische Akademie der Wissenschaften, Munich, Germany, 6-10 October 2010; pp. 35-38.

6. De Freitas, C.R.; Scott, D.; McBoyle, G. A second generation climate index for tourism (CIT): Specification and verification. Int. J. Biometeorol. 2008, 52, 399-407. [CrossRef] [PubMed]

7. Höppe, P. The physiological equivalent temperature-A universal index for the biometeorological assessment of the thermal environment. Int. J. Biometeorol. 1999, 43, 71-75. [CrossRef]

8. Jendtritzky, G.; de Dear, R.; Havenith, G. UTCI-Why another thermal index? Int. J. Biometeorol. 2012, 56, 421-428. [CrossRef]

9. Błażejczyk, K.; Broede, P.; Fiala, D.; Havenith, G.; Holmer, I.; Jendritzky, G.; Kampmann, B. UTCI-New index for assessment of heat stress in man. Przegl. Geogr. 2010, 82, 49-71.

10. Błażejczyk, K.; Broede, P.; Fiala, D.; Havenith, G.; Holmer, I.; Jendritzky, G.; Kampmann, B.; Kunert, A. Principles of the New Universal Thermal Climate Index (UTCI) and its Application to Bioclimatic Research in European Scale. Misc. Geogr. 2018, 14, 91-102. [CrossRef]

11. Kozłowska-Szczęsna, T. (Ed.) Problemy Bioklimatologii Uzdrowiskowej (Problems of Health Resorts Bioclimatology); Dokumentacja Geograficzna 3-4; IGiPZ PAN: Warsaw, Poland, 1975; p. 113.

12. Błażejczyk, K. Biotermiczne warunki klimatoterapii i rekreacji w wybranych uzdrowiskach Polski (Bio-thermal conditions of climatotherapy and recreation in selected jealth resorts of Poland). Balneol. Pol. 2000, 42, 98-104.

13. Kozłowska-Szczęsna, T. Stan Badań Klimatu i Bioklimatu Uzdrowisk Polskich (The State of Research on the Climate and Bioclimate of Polish Health Resorts); Dokumentacja Geograficzna; IGiPZ PAN: Warsaw, Poland, 2000; p. 61.

14. Kozłowska-Szczęsna, T.; Błażejczyk, K.; Krawczyk, B.; Limanówka, D. Bioklimat Uzdrowisk Polskich i Możliwości Jego Wykorzystania $w$ Lecznictwie (Bioclimate of Polish Health Resorts and the Opportunities for Its Use in Treatment); Monografie IGiPZ PAN: Warsaw, Poland, 2002; p. 611.

15. Martinez-Austria, P.; Bandala, E.R. Heat Waves: Health Effects, Observed Trends and Climate Change. In Extreme Weather; Sallis, J., Ed.; IntechOpen: London, UK, 2018; pp. 107-123.

16. Della-Marta, P.M.; Beniston, M. Summer Heat Waves in Western Europe, Their Past Change and Future Projections. In Climate Variability and Extremes during the Past 100 Years; Brönnimann, S., Luterbacher, J., Ewen, T., Diaz, H.F., Eds.; Springer: Dordrecht, The Netherlands, 2008; Volume 33, pp. 235-250.

17. Stefanon, M.; D'Andrea, F.; Drobinski, F. Heat wave classification over Europe and the Mediterranean region. Environ. Res. Lett. 2012, 7, 014023. [CrossRef]

18. Dankers, R.; Hiederer, R. Extreme Temperatures and Precipitation in Europe: Analysis of a High-Resolution Climate Change Scenario; Office for Official Publications of the European Communities: Luxembourg, 2008; p. 66.

19. Twardosz, R.; Kossowska-Cezak, U. Exceptionally hot summers in Central and Eastern Europe (1951-2010). Theor. Appl. Climatol. 2013, 112, 617-628. [CrossRef]

20. Russo, S.; Sillmann, J.; Fischer, E.M. Top ten European heat waves since 1950 and their occurrence in the coming decades. Environ. Res. Lett. 2015, 10, 124003. [CrossRef]

21. Zacharias, S.; Koppe, C.; Mücke, H.-G. Climate Change Effects on Heat Waves and Future Heat Wave-Associated IHD Mortality in Germany. Climate 2015, 3, 100-117. [CrossRef]

22. Tomczyk, A.M.; Sulikowska, A. Heat waves in lowland Germany and their circulation-related conditions. Meteorol. Atmos. Phys. 2017, 130, 1-17. [CrossRef]

23. Di Napoli, C.; Pappenberger, F.; Cloke, H.L. Assessing heat-related health risk in Europe via the Universal Thermal Climate Index (UTCI). Int. J. Biometeorol. 2018, 62, 1155-1165. [CrossRef]

24. Wibig, J. Heat waves in Poland in the period 1951-2015: Trends, patterns and driving factors. Meteorol. Hydrol. Water Manag. 2018, 6, 37-45. [CrossRef]

25. Tomczyk, A.M.; Bednorz, E.; Półrolniczak, M.; Kolendowicz, L. Strong heat and cold waves in Poland in relation with the large-scale atmospheric circulation. Theor. Appl. Climatol. 2018, 137, 1909-1923. [CrossRef]

26. Tomczyk, A.M.; Bednorz, E. Heat waves in Central Europe and tropospheric anomalies of temperature and geopotential heights. Int. J. Climatol. 2019, 39, 4189-4205. [CrossRef]

27. Fenner, D.; Holtmann, A.; Krug, A.; Scherer, D. Heat waves in Berlin and Potsdam, Germany-Long-term trends and comparison of heat wave definitions from 1893 to 2017. Int. J. Climatol. 2019, 39, 2422-2437. [CrossRef]

28. Urban, A.; Kisely, J.; Plavcova, E.; Hanzlikova, H.; Stepanek, P. Temporal changes in years of life lost associated with heat waves in the Czech Republic. Sci. Total Environ. 2020, 716, 137093. [CrossRef]

29. Black, E.; Blackburn, M.; Harrison, G.; Hoskins, B.; Methven, J. Factors contributing to the summer 2003 European heat wave. Weather 2004, 59, 217-223. [CrossRef]

30. Garcia-Herrera, R.; Diaz, J.; Trigo, R.M.; Luterbacher, J.; Fischer, E.M. A review of the European summer heat wave of 2003. Crit. Rev. Environ. Sci. Technol. 2010, 40, 267-300. [CrossRef]

31. Rebetez, M.; Dupond, O.; Gailard, M.G. An analysis of the July 2006 heat wave extent in Europe compared to the record year of 2003. Theor. Appl. Climatol. 2009, 95, 1-7. [CrossRef] 
32. Chiriaco, M.; Bastin, S.; Yiou, P.; Haeffelin, M.; Dupont, J.-C.; Stéfanon, M. European heat wave in July 2006: Observations and modeling showing how local processes amplify conducive large-scale conditions. Geophys. Res. Lett. 2014, 41, 5644-5652. [CrossRef]

33. Urban, A.; Hanzlikova, H.; Kysely, J.; Plavcova, E. Impacts of the 2015 Heat Waves on Mortality in the Czech Republic-A Comparison with Previous Heat Waves. Int. J. Environ. Res. Public Health 2017, 14, 1562. Available online: https:/ /www.mdpi. com/1660-4601/14/12/1562 (accessed on 1 May 2021). [CrossRef]

34. Kornhuber, K.; Ospray, S.; Coumou, D.; Petri, S.; Petoukhov, V.; Rahmstorf, S.; Gray, L. Extreme weather events in early summer 2018 connected by a recurrent hemispheric wave-7 pattern. Environ. Res. Lett. 2019, 14, 054002. [CrossRef]

35. Tomczyk, A.M.; Bednorz, E. The extreme year-analysis of thermal conditions in Poland in 2018. Theor. Appl. Climatol. 2020, 139, 251-260. [CrossRef]

36. Zhao, W.; Zhao, N.; Chen, S. The Record-Breaking High Temperature over Europe in June of 2019. Atmosphere 2020, 11, 524. [CrossRef]

37. Twardosz, R.; Wałach, P. Niezwykle ciepła pogoda w czerwcu 2019 roku w Polsce i jej przyczyny cyrkulacyjne (Unusually hot June 2019 in Poland and its circulation related causes). Przegl. Geofiz. 2020, 65, 179-194.

38. Ragettli, M.S.; Schindler, C.; Röösli, M. Excess mortality during the warm summer of 2015 in Switzerland. Swiss Med. Wkly. 2017, $146,14379$.

39. Muthers, S.; Laschewski, G.; Matzarakis, A. The summers 2003 and 2015 in South-West Germany: Heat waves and heat-related mortality in the context of climate change. Atmosphere 2017, 8, 224. Available online: https://www.mdpi.com/2073-4433/8/11/2 24 (accessed on 1 May 2021). [CrossRef]

40. Gabriel, K.; Endlicher, W. Urban and rural mortality rates during heat waves in Berlin and Brandenburg, Germany. Environ. Pollut. 2011, 159, 2044-2050. [CrossRef] [PubMed]

41. Robine, J.M.; Cheung, S.L.; Le Roy, S.; Van Oyen, H.; Griffiths, C.E.; Michel, J.-P.; Herrmann, F.R. Death toll exceeded 70,000 in Europe during the summer of 2003. Comptes Rendus Biol. 2008, 331, 171-178. [CrossRef] [PubMed]

42. Výberči, D.; Švec, M.; Faško, P.; Savinová, H.; Trizna, M.; Mičietová, E. The effects of the 1996-2012 summer heat events on human mortality in Slovakia. Morav. Geogr. Rep. 2015, 23, 58-70.

43. Graczyk, D.; Kundzewicz, Z.W.; Choryński, A.; Førland, E.J.; Pińskwar, I.; Szwed, M. Heat-related mortality during hot summers in Polish cities. Theor. Appl. Climatol. 2019, 136, 1259-1273. [CrossRef]

44. Hutter, H.-P.; Moshammer, H.; Wallner, R.; Leitner, P.; Kundi, M. Heatwaves in Vienna: Effects on mortality. Wien Klin. Wochenschr. 2007, 119, 223-227. [CrossRef] [PubMed]

45. Páldy, A.; Bobvos, J.; Vámos, A.; Kovats, R.S.; Hajat, S. The effect of temperature and heat waves on daily mortality in Budapest, Hungary, 1970-2000. In Extreme Weather Events and Public Health Responses; Kirch, W., Menne, B., Bertollini, R., Eds.; Springer: Berlin/Heidelberg, Germany, 2005; pp. 99-107.

46. Błażejczyk, K.; Kunert, A. Bioklimatyczne Uwarunkowania Rekreacji i Turystyki w Polsce (Bioclimatic Principles of Recreation and Tourism in Poland); Polish Academy of Sciences S. Leszczycki Institute of Geography and Spatial Organization, Monographies: Warsaw, Poland, 2011; p. 365.

47. Błażejczyk, A.; Błażejczyk, K.; Baranowski, J.; Kuchcik, M. Heat stress mortality and desired adaptation responses of healthcare system in Poland. Int. J. Biometeorol. 2018, 62, 307-318. [CrossRef]

48. Kuchcik, M.; Błażejczyk, K.; Szmyd, J.; Milewski, P.; Błażejczyk, A.; Baranowski, J. Potencjał Leczniczy Klimatu Polski (The Therapeutic Potential of the Polish Climate); IGIPZ PAN, Wydawnictwo Akademickie Sedno: Warsaw, Poland, 2013; p. 272.

49. Owczarek, M. The influence of large-scale factors on the heat load on human beings in Poland in the summer months. Theor. Appl. Climatol. 2018, 137, 855-869. [CrossRef]

50. Bartoszek, K.; Wereski, S.; Krzyżewska, A.; Dobek, M. The influence of atmospheric circulation on bioclimatic conditions in Lublin (Poland). Bull. Geogr. Phys. Geogr. Ser. 2017, 12, 41-49. [CrossRef]

51. Krzyżewska, A.; Wereski, S.; Dobek, M. Summer UTCI variability in Poland in the twenty-first century. Int. J. Biometeorol. 2020. Available online: https://link.springer.com/article/10.1007/s00484-020-01965-2 (accessed on 1 May 2021). [CrossRef]

52. Tomczyk, A.M.; Owczarek, M. Occurrence of strong and very strong heat stress in Poland and its circulation conditions. Theor. Appl. Climatol. 2020, 139, 893-905. [CrossRef]

53. Półrolniczak, M.; Szyga, K.; Kolendowicz, L. Bioklimat wybranych miast pasa Pobrzeży Południowobałtyckich na podstawie uniwersalnego wskaźnika obciążenia cieplnego (Bioclimate of the chosen cities in the Polish Baltic Coast based on Universal Thermal Climate Index). Acta Geogr. Lodz. 2016, 104, 147-161.

54. Kolendowicz, L.; Połrolniczak, M.; Szyga-Pluta, K.; Bednorz, E. Human-biometeorological conditions in the southern Baltic coast based on the universal thermal climate index (UTCI). Theor. Appl. Climatol. 2018, 134, 363-379. [CrossRef]

55. Nemeth, A. Changing thermal bioclimate in some Hungarian cities. Acta Climatol. Chorol. Univ. Szeged. 2011, 44-45, 93-101.

56. Bleta, A.; Nastos, P.T.; Matzarakis, A. Assessment of bioclimatic conditions on Crete Island, Greece. Reg. Environ. Chang. 2014, 14, 1967-1981. [CrossRef]

57. Pecelj, M.; Đorđević, A.; Pecelj, M.R.; Pecelj-Purković, J.; Filipović, D.; Šećerov, V. Biothermal conditions on Mt. Zlatibor based on thermophysiological indices. Arch. Biol. Sci. 2017, 69, 455-461. [CrossRef] 
58. Morabito, M.; Crisci, A.; Messeri, A.; Capecchi, V.; Modesti, P.A.; Gensini, G.F.; Orlandini, S. Environmental temperature and thermal indices: What is the most effective predictor of heat-related mortality in different geographical contexts? Sci. World J. 2014, 2014, 1-15. [CrossRef]

59. Novak, M. Use of the UTCI in the Czech Republic. Geogr. Pol. 2013, 86, 21-28. [CrossRef]

60. Urban, A.; Kisely, J. Comparison of UTCI with other thermal indices in the assessment of heat and cold effects on cardiovascular mortality in the Czech Republic. Int. J. Environ. Res. Public Health 2014, 11, 952-967. [CrossRef]

61. Matzarakis, A.; Muthers, S.; Rutz, F. Application and comparison of UTCI and PET in temperate climate conditions. Finisterra 2014, 49, 21-31. [CrossRef]

62. Brecht, B.M.; Schädler, G.; Schipper, J.W. UTCI climatology and its future change in Germany-An RCM ensemble approach. Meteorol. Z. 2020, 29, 97-116. [CrossRef]

63. Kažys, J.; Malūnavičiūtè, I. The evaluation of summer beaching conditions on the Baltic Sea coast using the UTCI index. Int. J. Clim. Chang. Impacts Resp. 2015, 7, 41-59. [CrossRef]

64. Plavcová, E.; Kyselý, J. Overly persistent circulation in climate models contributes to overestimated frequency and duration of heat waves and cold spells. Clim. Dyn. 2016, 46, 2805-2820. [CrossRef]

65. Kuchcik, M. Mortality and thermal environment (UTCI) in Poland-long-term, multi-city study. Int. J. Biometeorol. 2020, 1-13. Available online: https:/ /link.springer.com/content/pdf/10.1007/s00484-020-01995-w.pdf (accessed on 1 May 2021). [CrossRef]

66. Bryś, K.; Ojrzyńska, H. Stimulating qualities of biometeorological conditions in Wrocław. Acta Geogr. Lodz. Folia Geogr. Phys. 2016, 104, 193-200.

67. Miszuk, B. Intensity of heat stress in 2015 and 2018 summer seasons in the region of the Lower Silesia (Poland). Misc. Geogr. 2020, 24, 3. Available online: http:/ / cejsh.icm.edu.pl/cejsh/element/bwmeta1.element.desklight-131fd5e4-679e-497f-85ba-f41360 6 fc462 (accessed on 1 May 2021). [CrossRef]

68. Miszuk, B. Multi-Annual Changes in Heat Stress Occurrence and Its Circulation Conditions in the Polish-Saxon Border Region. Atmopshere 2021, 12, 163.

69. Mehler, S.; Völlings, A.; Flügel, I.; Szymanowski, M.; Błaś, M.; Sobik, M.; Migała, K.; Werner, M.; Kryza, M.; Miszuk, B.; et al. Zmiany Klimatu w Regionie Granicznym Polski i Saksonii (Climate Changes in the Polish-Saxon Border Region); Sächsisches Landesamt für Umwelt, Landwirtschaft und Geologie: Dresden, Germany, 2014; p. 80.

70. Milewski, P. Application of the UTCI to the local bioclimate of Poland's Ziemia Kłodzka region. Geogr. Pol. 2013, 86, 47-54. [CrossRef]

71. Ketterer, C.; Matzarakis, A. The tourism climate of Engadin, Switzerland. In Proceedings of the 7th Conference on Biometeorology, Freiburg, Germany, 12-14 April 2010; Mazarakis, A., Mayer, H., Chmielewski, F.-M., Eds.; Albert-Ludwigs-University of Freiburg: Freiburg, Germany, 2010; pp. 398-403.

72. Matzarakis, A.; Hammerle, M.; Koch, E.; Rudel, E. The climate tourism potential of Alpine destinations using the example of Sonnblick, Rauris and Saltzburg. Theor. Appl. Climatol. 2012, 110, 645-658. [CrossRef]

73. Matzarakis, A.; Endler, C. Climate-Tourism-Information-Scheme. In Proceedings of the 7th Conference on Biometeorology, Freiburg, Germany, 12-14 April 2010; Mazarakis, A., Mayer, H., Chmielewski, F.-M., Eds.; Albert-Ludwigs-University of Freiburg: Freiburg, Germany, 2010; pp. 392-397.

74. Oehler, K.; Maztarakis, A. Climate change and tourism potential in the Black Forest-A tourism and climate approach for forest areas. In Developments in Tourism Climatology; Matzarakis, A., de Freitas, C.R., Scott, D., Eds.; Commission Climate, Tourism and Recreation, International Society of Biometeorology: Freiburg, Germany, 2007; pp. 267-273.

75. Basarin, B.; Krzić, A.; Lazić, L.; Lukic, T.; Dordević, J.; Janićijenović-Petrović, B.; Ćopić, S.; Matić, D.; Hrniak, I.; Matzarakis, A. Evaluation of bioclimate conditions in two special nature reserves in Vojvodina (Northern Serbia). Carpathian J. Earth Environ. Sci. 2014, 9, 93-108.

76. Brosy, C.; Zaninovic, K.; Matzarakis, A. Quantification of climate tourism potential of Croatia based on measured data and regional modeling. Int. J. Biometeorol. 2014, 58, 1369-1381. [CrossRef]

77. Matzarakis, A. Transfer of climate data for tourism applications-The Climate-Tourism/Transfer-Information-Scheme. Sustain. Environ. Res. 2014, 24, 273-280.

78. Mihăilă, D.; Bistricean, P.-I.; Briciu, A.-E. Assessment of the climate potential for tourism. Case study: The North-East Development Region of Romania. Theor. Appl. Climatol. 2019, 137, 601-622. [CrossRef]

79. Zaninovic, K.; Matzarakis, A. The bioclimatological leaflet as a means conveying climatological information to tourists and the tourism industry. Int. J. Biometeorol. 2009, 53, 369-374. [CrossRef] [PubMed]

80. Owczarek, M.; Chlost, I. Klimatyczne elementy potencjału rekreacyjnego Słowińskiego Parku Narodowego (Climatic aspects of recreational potential in Słowiński National Park). In Turystyka i Turysta Nad Bałtykiem; Szmytkowska, M., Ed.; Gdańskie Teki Turystyczno-Krajoznawcze, Wydawnictwo Uniwersytetu Gdańskiego: Gdańsk, Poland, 2017; Volume 2, pp. $176-193$.

81. Miszuk, B.; Otop, I.; Owczarek, M. Warunki bioklimatyczne jako czynnik kształtujący potencjał rekreacyjny Sudetów (Bioclimatic conditions as a factor shaping the recreational potential of the Sudetic Mountains). Przegl. Geogr. 2012, 3, 437-446. [CrossRef]

82. Miszuk, B.; Otop, I.; Strońska, M.; Schwarzak, S.; Surke, M. Tourism-climate conditions and their future development in the Polish-Saxon border area. Meteorol. Z. 2016, 25, 421-434. 
83. Fiala, D.; Lomas, K.J.; Stohrer, M. Computer prediction of human thermoregulatory and temperature responses to a wide range of environmental conditions. Int. J. Biometeorol. 2001, 45, 143-159. [CrossRef]

84. Błażejczyk, K.; Błażejczyk, M. Bioklima2.6, Software Package. 2010. Available online: https://www.igipz.pan.pl/Bioklima-zgik. html (accessed on 1 May 2021).

85. Ojrzyńska, H. Cyrkulacyjne Uwarunkowania Przestrzennego Rozkładu Temperatury Powietrza w Terenie Zróżnicowanym Morfologicznie Na Przykładzie Sudetów (Circulation Conditionings of Air Temperature Spatial Differentiation in Morphologically Diverse Area with the Use of an Example of the Western Sudeten); Rozprawy Naukowe Instytutu Geografii i Rozwoju Regionalnego Uniwersytetu Wrocławskiego: Wrocław, Poland, 2015; p. 228.

86. Ojrzyńska, H.; Bilińska, D.; Werner, M.; Kryza, M.; Malkiewicz, M. The influence of atmospheric circulation conditions on Betula and Alnus pollen concentrations in Wrocław, Poland. Aerobiologia 2020, 36, 261-276. [CrossRef]

87. Ojrzyńska, H. Calendar of circulation types for 1971-2010. Obtained Directly from the Author (University of Wrocław, Wrocław, Poland). Unpublished work.

88. Owczarek, M.; Filipiak, J. Contemporary changes of thermal conditions in Poland, 1951-2015. Bull. Geogr. Phys. Geogr. 2016, 10, 31-50. [CrossRef]

89. Nowosad, M.; Rodzik, B.; Wereski, S.; Dobek, M. The UTCI index in Lesko and Lublin and its circulation determinants. Geogr. Pol. 2013, 86, 29-56. [CrossRef]

90. Błażejczyk, K.; Kuchcik, M.; Błażejczyk, A.; Milewski, P.; Szmyd, J. Assessment of urban thermal stress by UTCI—Experimental and modelling studies: An example from Poland. DIE ERDE 2013, 45, 16-33.

91. Basarin, B.; Lukić, T.; Matzarakis, A. Review of Biometeorology of Heatwaves and Warm Extremes in Europe. Atmosphere 2020, 11, 1276. [CrossRef]

92. Scott, D.; Lemieux, C. Weather and climate information for tourism. Procedia Environ. Sci. 2010, 1, 146-183. [CrossRef]

93. Błażejczyk, K.; Nejedlik, P.; Skrynyk, O.; Halaś, A.; Skrynyk, O.; Baranowski, J.; Mikulova, K. Thermal stress in the northern Carpathians and air circulation. Misc. Geogr. 2020, 24, 147-160.

94. Urban, G. Zaleganie pokrywy śnieżnej i jego zmienność w polskiej części Sudetów i na ich przedpolu (Duration of snow cover and its variability in the Polish part of the Sudetes Mts. and their foreland). Przegl. Geogr. 2015, 87, 497-516. [CrossRef]

95. Błażejczyk, K.; Idzikowska, D.; Błażejczyk, A. Forecast changes for heat and cold stress in Warsaw in the 21st century, and their possible influence on mortality risk. Pap. Glob. Chang. 2013, 20, 47-62. [CrossRef]

96. Schwarzak, S.; Völlings, A.; Surke, M.; Kryza, M.; Szymanowski, M.; Błaś, M.; Werner, M.; Sobik, M.; Migała, K.; Miszuk, B.; et al. Projekcje Klimatu, Zanieczyszczenia Powietrza i Ładunki Krytyczne w Regionie Granicznym Polski i Saksonii (Climate Projections, Air Pollution and Critical Loads in the Polish-Saxon Border Region); Sächsisches Landesamt für Umwelt, Landwirtschaft und Geologie: Dresden, Germany, 2014; p. 90. 